Provided for non-commercial research and education use. Not for reproduction, distribution or commercial use.

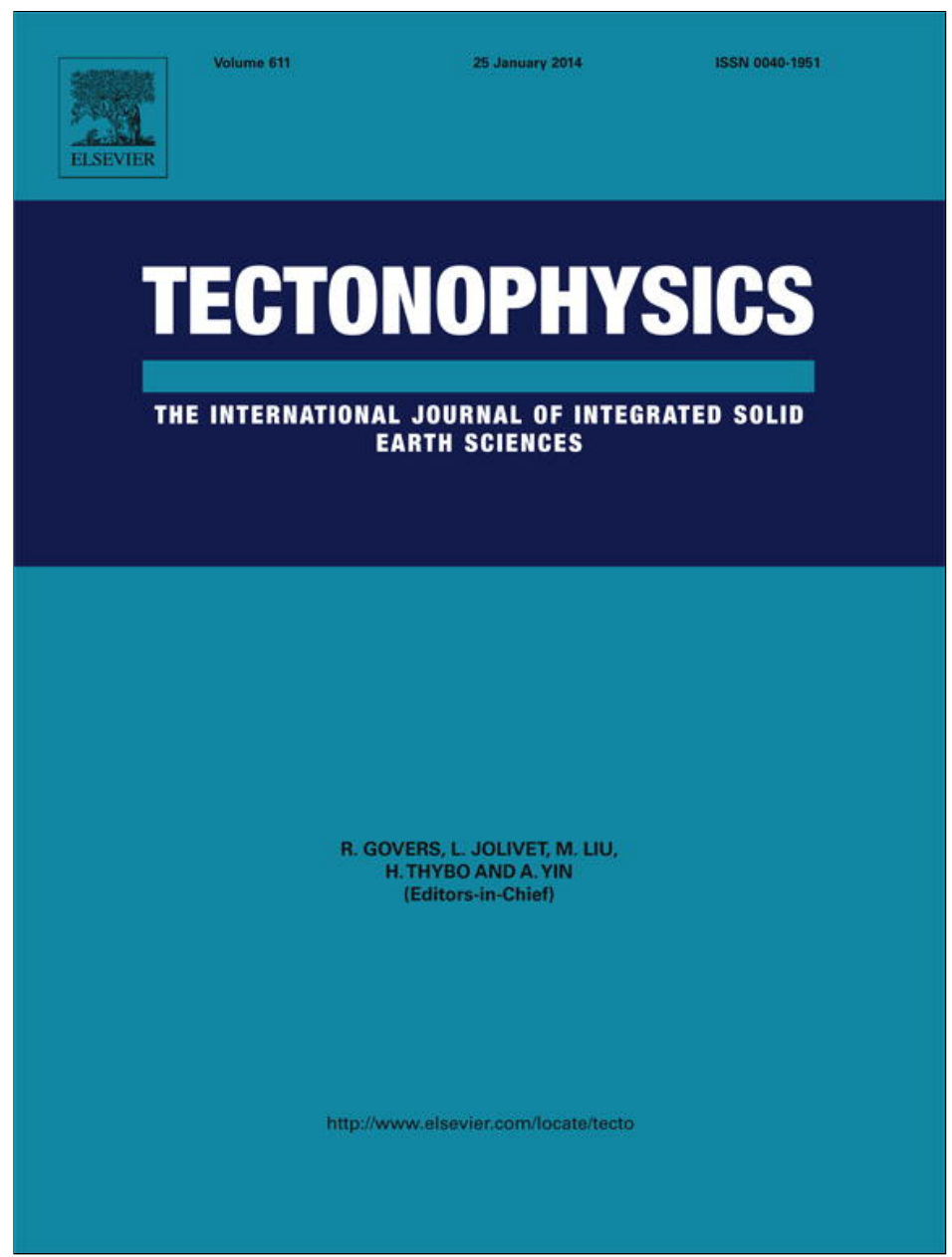

This article appeared in a journal published by Elsevier. The attached copy is furnished to the author for internal non-commercial research and education use, including for instruction at the authors institution and sharing with colleagues.

Other uses, including reproduction and distribution, or selling or licensing copies, or posting to personal, institutional or third party websites are prohibited.

In most cases authors are permitted to post their version of the article (e.g. in Word or Tex form) to their personal website or institutional repository. Authors requiring further information regarding Elsevier's archiving and manuscript policies are encouraged to visit:

http://www.elsevier.com/authorsrights 
Review Article

\title{
Tectonic reconstructions for paleobathymetry in Drake Passage
}

\author{
Graeme Eagles $^{\mathrm{a}, *}$, Wilfried Jokat ${ }^{\mathrm{b}}$ \\ a Department of Earth Sciences, Royal Holloway University of London, Egham, Surrey TW20 0EX, United Kingdom \\ ${ }^{\mathrm{b}}$ Alfred Wegener Institute, Helmholtz Centre for Polar and Marine Research, Am Alten Hafen 26, Bremerhaven D-27568, Germany
}

\section{A R T I C L E I N F O}

\section{Article history:}

Received 17 July 2013

Received in revised form 30 October 2013

Accepted 16 November 2013

Available online 28 November 2013

\section{Keywords:}

Ocean gateways

Antarctic circumpolar current

Plate motions

Paleobathymetry

Southern Ocean

Global change

\begin{abstract}
A B S T R A C T
A minimum-complexity tectonic reconstruction, based on published and new basin opening models, depicts how the Scotia Sea grew by Cenozoic plate divergence, dismembering a Jurassic sheared margin of Gondwana. Part of the Jurassic-early Cretaceous ocean that accreted to this margin forms the core of the Central Scotia Plate, the arc plate above a trench at the eastern end of the Scotia Sea, which migrated east away from the Antarctic and South American plates. A sequence of extensional basins opened on the western edge of the Central Scotia Plate at 50$30 \mathrm{Ma}$, decoupled from the South American Plate to the northwest by slow motion on a long transform fault. Succeeding the basins, seafloor spreading started around 30 Ma on the West Scotia Ridge, which propagated northwards in the 23-17 Ma period and ceased to operate at $6 \mathrm{Ma}$. The circuits of plate motions inside and outside the Scotia Arc are joined via rotations that describe Antarctic-Central Scotia plate motion in Powell Basin until $20 \mathrm{Ma}$, and along the South Scotia Ridge thereafter. The modelled relative motion at the northern edge of the Scotia Sea is thus constrained only by the plate circuit, but nonetheless resembles that known coarsely from the geological record of Tierra del Fuego. A paleobathymetric interpretation of nine time slices in the model shows Drake Passage developing as an intermediate-depth oceanographic gateway at 50-30 Ma, with deep flow possible afterwards. Initially, this deep flow would have been made tortuous by numerous intermediate and shallow barriers. A frontal pattern resembling that in the modern Scotia Sea would have awaited the clearance of significant barriers by continuing seafloor spreading in the Scotia Sea at $~ 18.5 \mathrm{Ma}$, at Shag Rocks Passage, and after 10 Ma southeast of South Georgia.
\end{abstract}

(c) 2013 Elsevier B.V. All rights reserved.

\section{Contents}

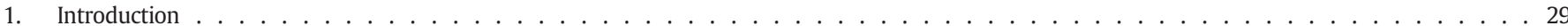

2. Tectonic studies of the Scotia Sea . . . . . . . . . . . . . . . . . . . . . . . . . . . . . . . . . . . 29

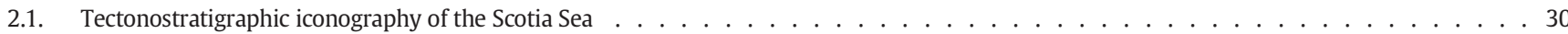

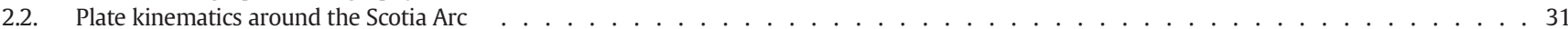

2.2.1. South American-Antarctic plate divergence . . . . . . . . . . . . . . . . . . . . . . . . . . . . . . . . . . . . . . . . . . . . . . . . . . . 31

2.2.2. Jane Basin . . . . . . . . . . . . . . . . . . . . . . . . . . . . . . . . 32

2.2.3. Phoenix-Antarctic system . . . . . . . . . . . . . . . . . . . . . . . . . . . . . . . . 32

2.2.4. Bransfield Strait . . . . . . . . . . . . . . . . . . . . . . . . . . . . . . . . 32

2.3. Plate kinematics within the Scotia Arc . . . . . . . . . . . . . . . . . . . . . . . . . . . . . . . . . . . . . . . . 32

2.3.1. East Scotia Sea . . . . . . . . . . . . . . . . . . . . . . . . . . . . . . . . . 33

2.3.2. West Scotia Sea . . . . . . . . . . . . . . . . . . . . . . . . . . . . . . . . . . . . 33

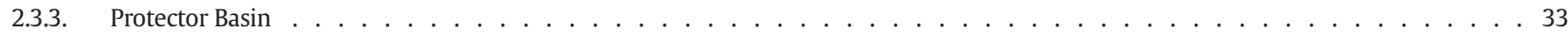

2.3.4. Dove Basin . . . . . . . . . . . . . . . . . . . . . . . . . . . . . . . . . . . . . . . 34

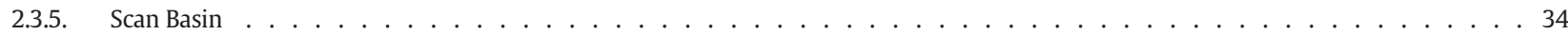

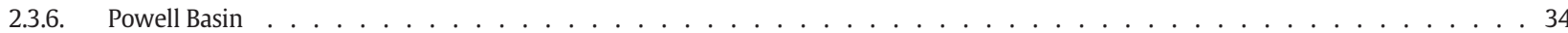

2.3.7. Central Scotia Sea

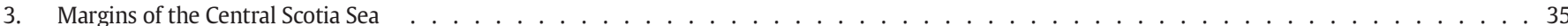

4. New Euler rotations for basin reconstructions . . . . . . . . . . . . . . . . . . . . . . . . . . . . . . . . . . . . . . . . . . . . . . . . . . . . .

4.1. East Scotia Sea . . . . . . . . . . . . . . . . . . . . . . . . . . . . . . . . 35

4.2. The earliest west Scotia Sea and the Scan, Dove and Protector Basins . . . . . . . . . . . . . . . . . . . . . . . . . . . . . . . 36

* Corresponding author at: Alfred Wegener Institute, Helmholtz Centre for Polar and Marine Research, Am Alten Hafen 26, Bremerhaven D-27568, Germany. Tel.: + 44 1784 443890; fax: +441784471780 .

E-mail address: graeme.eagles@rhul.ac.uk (G. Eagles). 
5. Fitting the Scotia Sea into the regional plate circuit . . . . . . . . . . . . . . . . . . . . . . . . . . . . 37

6. Tectonic reconstructions of the Scotia Sea . . . . . . . . . . . . . . . . . . . . . . . . . . . . . . . . . . . . . . . . . . . 37

6.1. Before the Scotia Sea $50 \mathrm{Ma}$. . . . . . . . . . . . . . . . . . . . . . . . . . . . . . . . . . . . . . 38

6.2. Earliest seafloor spreading: $41 \mathrm{Ma}$. . . . . . . . . . . . . . . . . . . . . . . . . . . . . . . . . . . . . 39

6.3. The Central Scotia Plate grows: $33 \mathrm{Ma}$. . . . . . . . . . . . . . . . . . . . . . . . . . . . . . . . 40

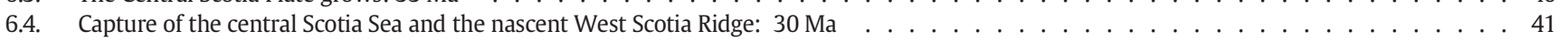

6.5. Organised seafloor spreading in the west Scotia Sea: $26 \mathrm{Ma}$. . . . . . . . . . . . . . . . . . . . . . . . . . . . . . . 41

6.6. Spreading ends in Powell Basin: $20 \mathrm{Ma}$. . . . . . . . . . . . . . . . . . . . . . . . . . . . . . . . . . . . . . . . 43

6.7. Rupture of the Central Scotia Plate: $17 \mathrm{Ma}$. . . . . . . . . . . . . . . . . . . . . . . . . . . . . . 43

6.8. The senescent West Scotia Ridge: $10 \mathrm{Ma}$. . . . . . . . . . . . . . . . . . . . . . . . . . . . . . . . . . . 44

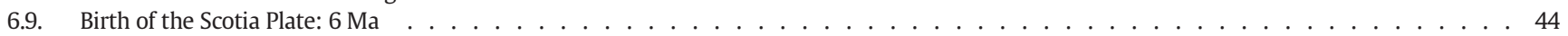

7. Discussion: Paleobathymetric development of Drake Passage . . . . . . . . . . . . . . . . . . . . . . . . . . . . . . . . 44

8. Conclusions . . . . . . . . . . . . . . . . . . . . . . . . . . . . . . . . . . . . . . . 47

Acknowledgements . . . . . . . . . . . . . . . . . . . . . . . . . . . . . . . . . . . . . 47

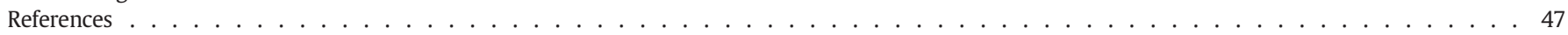

\section{Introduction}

Understanding of the Cenozoic growth of the Scotia Sea in the South Atlantic (Fig. 1) bears on a number of questions in other disciplines. Paleobiogeographical similarities between South America, Antarctica, Australia and Zealandia leave little doubt that a continental connection existed for much of Paleogene time between the Antarctic Peninsula and Patagonia. The loss of this interchange is important in understanding the colonisation of South America, Antarctica, Australia and Zealandia by their various mammal clades (Goin et al., 2006; Reguero and Marenssi, 2010; Woodburne and Case, 1996). Similarly, although it is certain that the region was inundated as the floor of the Scotia Sea widened and deepened, it is less well known by which times the Pacific and Atlantic oceans to the west and east became connected across it for shallow, intermediate, and deep water exchange (Pfuhl and McCave, 2005; Scher and Martin, 2006). Along with this it has long been debated whether the Antarctic Circumpolar Current, an oceanic frontal system that requires the existence of a deep ocean encircling Antarctica and through Drake Passage, was a direct driver of Antarctic glaciation and the accompanying global changes or a later consequence of it (De Conto and Pollard, 2003; Kennett, 1977). More recently, ocean and climate modelling experiments have led to suggestions that an intermediate, or even shallow (Ekman Layer; $<100 \mathrm{~m}$ ), oceanic connection at Drake Passage may have been sufficient to bring about global changes well before the conditions existed for the modern frontal system to exist (Sijp and England, 2005; Toggweiler and Bjornsson, 2000). The oceanic gateway through Drake Passage also played marine biogeographic roles, acting physically first as a connection and later as a barrier to shelf-dwelling taxa (Convey et al., 2009; González-Wevar et al., 2012), and elsewhere as a possible connection for mid-ocean ridge hydrothermal vent fauna (Roterman et al., 2013). The Antarctic frontal system was also important in the evolution and radiation of modern penguins and baleen whales (Baker et al., 2006; Fordyce, 2003; Hospitaleche et al., 2013; Steeman et al., 2009). Finally, the shrinking mantle of the subduction-bound Pacific Ocean has been suggested to be moving through the region beneath the Scotia Sea to mix with the expanding Atlantic mantle (Alvarez, 1982; Pearce et al., 2001).

These questions are frequently addressed in the light of paleogeographic information from hemisphere-scale plate reconstructions showing large plates that do not encapsulate the intricacies of the Scotia Sea's development (e.g. from the ODSN Plate Tectonic Reconstruction Service; Hay et al., 1999), or more detailed reconstructions led from tectonostratigraphic interpretations that are difficult to reconcile with the record of those intricacies as preserved in the floor of the Scotia Sea's various basins (e.g. Lawver et al., 1992, 2011). Although data sets and models concerning the growth of many of these basins exist (e.g. Eagles and Livermore, 2002; Eagles et al., 2005, 2006;
Vanneste and Larter, 2002), no detailed synthesis of them has been presented. To meet this need, we present a set of detailed tectonic reconstructions for the Scotia Sea, showing its development over the last 50 million years. Our approach is to combine Euler rotation models for the separation of the region's various continental elements. We favour Euler rotations from models built to recapitulate simple geophysical observations from the basins between the continents, rather than to support or illustrate any synthesis of derived regional tectonostratigraphic interpretations. In addition, we make explicit use of other plate tectonic considerations, firstly that plates should be internally rigid and secondly that the plate circuit east of the Pacific margin should be closed. We do this by considering the meanings of reconstruction underlaps and overlaps with respect to the geological history of the Scotia Sea and by depicting the minimum number of tectonic plates permitted by the constraints. Finally, we illustrate the resulting regional synthesis using reconstructions of a gridded bathymetric data set, and briefly discuss the reconstructions in terms of some of the wider questions outlined above.

\section{Tectonic studies of the Scotia Sea}

Today, the Scotia Sea is a collage of deep basins and shallower banks and swells that is encircled by a chain of islands and submarine banks called the Scotia Arc (Fig. 1). The complex stretches for more than $2500 \mathrm{~km}$ between Tierra del Fuego and the Antarctic Peninsula in the west, and the South Sandwich Islands in the east. Inside the Scotia Arc, the floor of the Scotia Sea consists of at least five deep basins on oceanic basement, as defined by interpretations of magnetic reversal isochrons, fracture zones, active or extinct mid-ocean ridges, and deep rough seismic basement without internal reflectivity (e.g. Barker et al., 1991; British Antarctic Survey, 1985). The three largest of these basins, from west to east, are known as the west, central and East Scotia seas. To the south of the west and central Scotia seas lie the smaller Protector and Dove basins, set apart from each other by the shallower areas known as Terror Rise, Pirie Bank and Bruce Bank. East of Bruce Bank lies a sixth basin, Scan basin, whose crustal nature is not known. A further bank, Discovery Bank, lies to the east of Scan Basin.

The long northern and southern arms of the Scotia Arc are referred to as the North and South Scotia ridges. The North Scotia Ridge begins at Staten Island off Tierra del Fuego, and continues eastwards via the relatively shallow submarine Burdwood, Davis, Barker (or Aurora) and Shag Rocks banks to the South Georgia microcontinent. Outcrops at Staten Island, Shag Rocks, and South Georgia are of Jurassic and Cretaceous continental rocks (British Antarctic Survey, 1985). South Georgia also bears a Jurassic ophiolite complex (Alabaster and Storey, 1990). The deep (>3 km) Falkland Trough lies to the north of the North Scotia Ridge. The South Scotia Ridge begins at the northern tip 


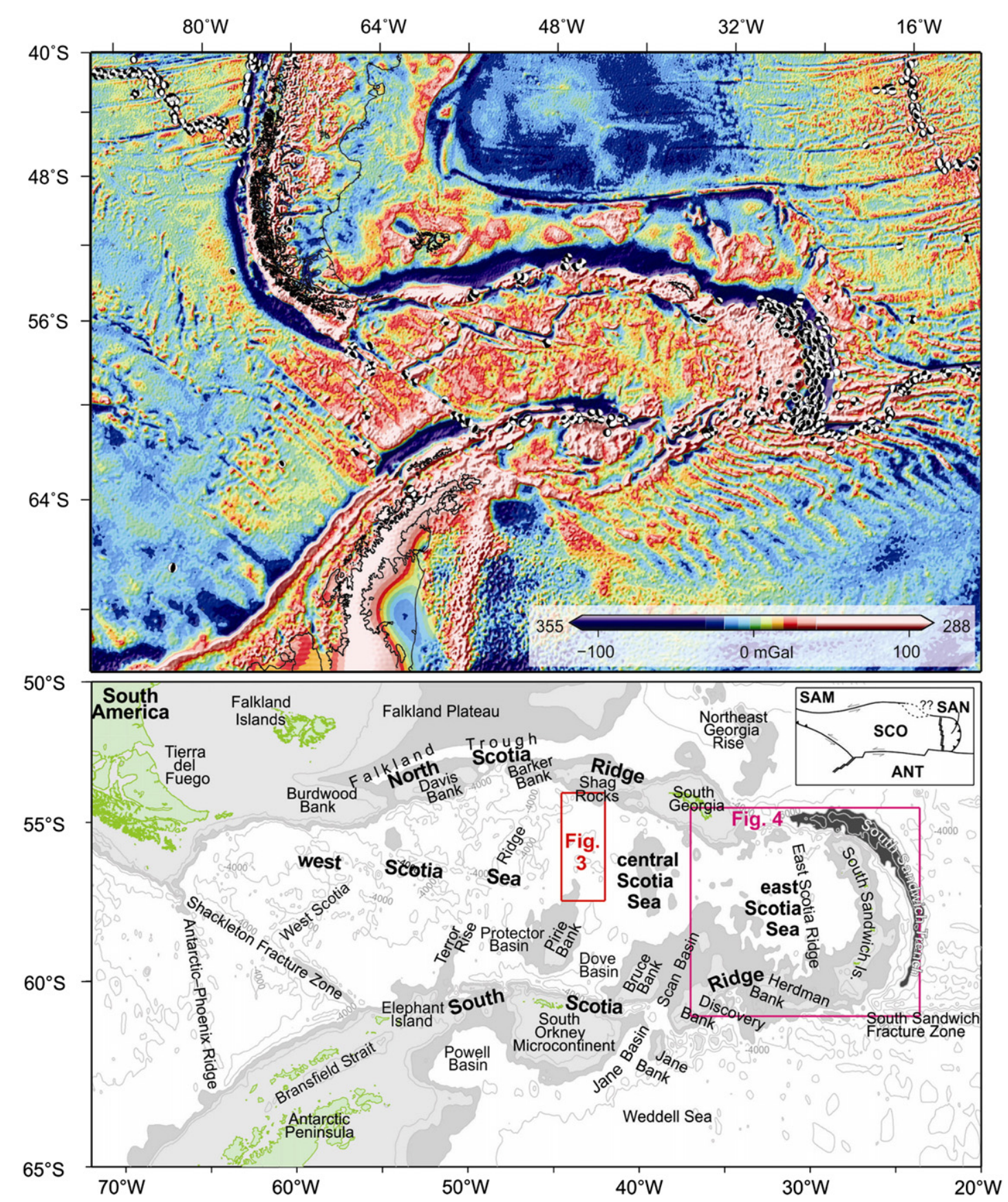

Fig. 1. Drake Passage, the Scotia Sea, and surrounding region. Top: satellite altimetry-derived free-air gravity data (Sandwell and Smith, 2009) with earthquake focal mechanisms (Dziewonski et al., 1981). Bottom: Place names used in text. Light grey shading, shallower than $2 \mathrm{~km}$; mid grey, shallower than 3 km; dark grey, deeper than 6 km. Inset: present plate boundaries.

of the Antarctic Peninsula, continuing eastwards via a narrow and heavily-dissected submarine bank with small island outcrops dominated by continental, subduction-related rocks of Paleozoic to Cretaceous ages (Dalziel, 1972). The eastern end of the South Scotia Ridge is the South Orkney Microcontinent where more Triassic and younger continental rocks are to be found (Dalziel et al., 1981). A small oceanic basin, Powell Basin, separates the microcontinent from the Antarctic Peninsula. To the east of the South Georgia and South Orkney microcontinents, the Scotia Arc closes via the active volcanic South Sandwich island arc and its submerged inactive ancestors at Jane and Discovery banks (Barker, 1995; Barker et al., 1982, 1984). The South Sandwich Islands lie on the western side of the deep South Sandwich Trench, and together form parts of an active subduction zone at which seafloor of the South American Plate is being thrust beneath the Scotia Plate.

\subsection{Tectonostratigraphic iconography of the Scotia Sea}

The nature and geological history of the region have been of interest since the 19th century. Barrow (1831) noted that the rocks of the South Shetland Islands, on the northwestern side of the Antarctic Peninsula, seem to mark a continuation of the Andes of Tierra del Fuego, being of 'precisely the same formation'. Arctowski (1895) developed this idea by sketching the hypothesis of the two areas as the emergent shoulders of an east-closing submarine orocline beneath the Scotia Sea. This idea was widely represented throughout the first half of the twentieth 
century as the presence of the Scotia Arc became known and dredging and outcrop mapping started to confirm its mostly-continental nature (Pirie, 1905; Suess, 1909; Tilley, 1935; Trendall, 1953, 1959).

The Scotia Arc came with time to be considered as the product of various ideas of a mobile crust, and ultimately of plate tectonics (Barker and Griffiths, 1972; Hawkes, 1962; Matthews, 1959; Wilson, 1966). Its constituents continued to be interpreted as having dispersed from the Antarctic Peninsula and Tierra del Fuego, which by now were presented as the products of convergent margin processes acting since Jurassic times. These interpretations were based on comparative tectonostratigraphy, most strikingly of the Cretaceous rocks of South Georgia and Tierra del Fuego (Dalziel, 1983; Dalziel and Elliot, 1971; Dalziel et al., 1975). Numerous attempts (e.g. Fig. 2), based on various plausible correlations were made to reconstruct a convergent Pacific margin prior to the Scotia Sea by interpreting and aligning tectonostratigraphic terranes in the Scotia Arc, Antarctic Peninsula and Tierra del Fuego (Dalziel, 1983; Garrett et al., 1986; King and Barker, 1988). On the basis of continental geology alone, these correlations remain difficult to evaluate decisively even today (Barbeau, 2011).

In attempts to discriminate between the various tectonostratigraphic arrangements, geophysical observations of the deeper parts of the Scotia Sea were used to determine the timing and orientation of extension in basins that formed as the parts of the Scotia Arc separated. In particular, this work focussed on the model ages and orientations of seafloor spreading-related magnetic anomalies. A group under Peter Barker at the University of Birmingham, and later the British Antarctic Survey, pioneered this work along with the PLATES group at the University of Texas. Barker $(1970,1972)$ assumed that most of the Scotia Sea's magnetically-lineated seafloor postdates $40 \mathrm{Ma}$, based on reliable parts of the magnetic reversal timescale at the time. The generally-shallow seafloor seemed to confirm this as understanding grew of the way in which normal oceanic lithosphere subsides with age, as it cools, becomes denser, and sinks into the underlying mantle (e.g. Parsons and Sclater, 1977; Stein and Stein, 1992). By this process, from a series of studies through the 1970s and 1980s (reviewed by Barker et al., 1991 and Barker, 2001), a regional plate kinematic synthesis was built to depict the assumption, going back to the 19th century, of a compact cuspate arrangement of continental blocks at Gondwana's Pacific margin. This synthesis is now the basis, in part or whole, for numerous regional tectonic compilations and data products (Brown et al., 2006; Lagabrielle et al., 2009; Müller et al., 2008; Vérard et al., 2012).

As well as being a non-unique, and to some even non-optimum, description of the tectonostratigraphic similarities (Dalziel, 1983), the synthesis is not flawless in its reconciliation of those similarities with the opening histories of the basins in the Scotia Sea. This is most starkly illustrated for South Georgia, which, if regarded as a close neighbour of Tierra del Fuego in Cretaceous times, has left no complete trace in the seafloor of the journey to its present location $1600 \mathrm{~km}$ further east (Cunningham et al., 1998; Dalziel et al., 2013a; Eagles, 2010a). Because of these difficulties, in the following we concentrate on the constraints available for reconstructing the tectonics of the Scotia Sea by optimising models of the basin floor's growth without any constraining assumptions about the shape, location, or tectonostratigraphy of the Scotia Arc in the past.

\subsection{Plate kinematics around the Scotia Arc}

Much of the floor of the Scotia Sea consists of oceanic lithosphere whose growth and motion would have been constrained by the evolving space created by relative motions of the surrounding larger plates. These motions constrain the growth of the Scotia Sea in as much as it is unreasonable to expect two reconstructed areas of present-day lithosphere to occupy the same space (that is, to overlap) without evidence for their extension since the time of the reconstruction, or to be separated by large distances (underlap) without evidence for later subduction or shortening. To use such constraints, it is first necessary to show how the plates surrounding the Scotia Sea moved with respect to each other.

\subsubsection{South American-Antarctic plate divergence}

The South American and Antarctic continents started moving with respect to each other in Jurassic times, as constituents of west and east Gondwana (Jokat et al., 2003; König and Jokat, 2006). Controversy haunts the issue of just how many plates were involved in this process. Nearly half of the intervening seafloor has been lost by subduction beneath the South Sandwich Islands and South Orkney Microcontinent. From what remains preserved in the Weddell Sea, patterns of fracture zones and magnetic isochrons are interpretable as having formed by the divergence of just two plates, the South American and Antarctic plates, since at least $150 \mathrm{Ma}$ and maybe since breakup beforehand (Eagles and Vaughan, 2009; Eagles et al., in preparation). Paleomagnetic studies on dykes from the Falkland Islands, however, suggest as much as $120^{\circ}$ of independent rotation of a third plate bearing the islands in Jurassic times (Stone et al., 2009; Taylor and Shaw, 1989).

Since $84 \mathrm{Ma}$, however, it is not disputed that only two plates were diverging north and south of what was to become the Scotia Sea, and that these plates were the South American and Antarctic plates (Cunningham et al., 1995; Eagles et al., in preparation; Livermore et al., 2005; Nankivell, 1997). Numerical models of this divergence

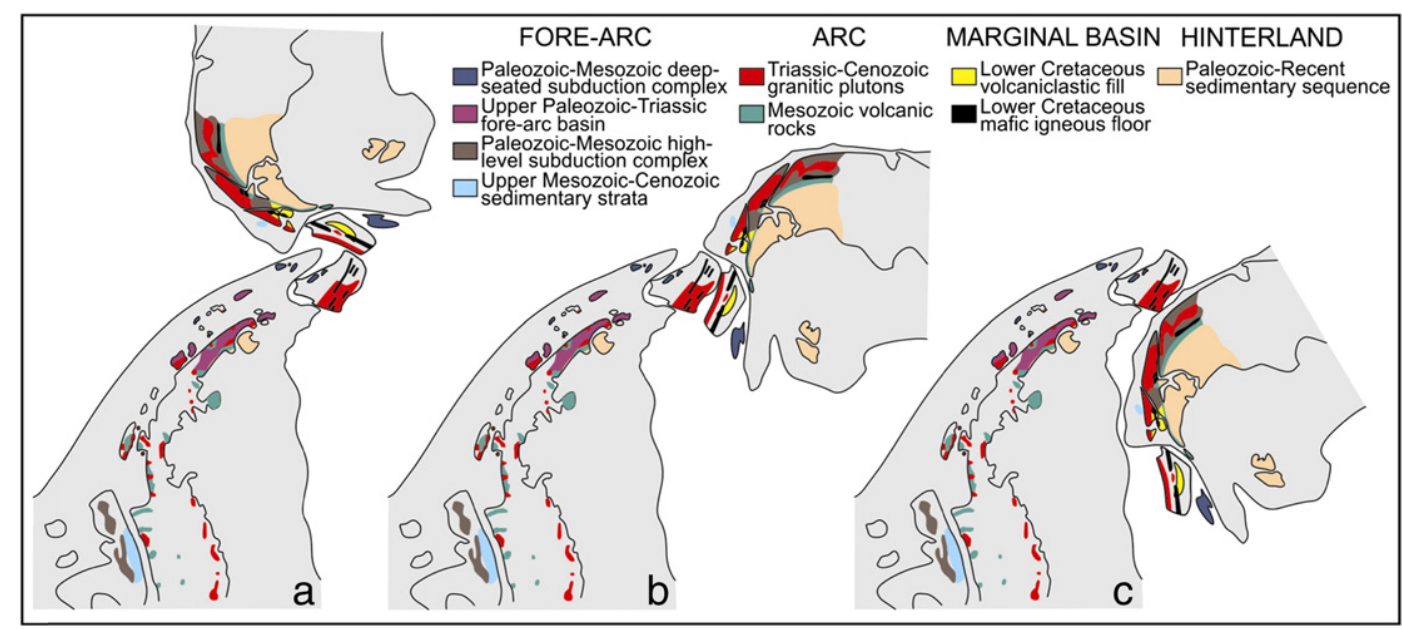

Fig. 2. Possible tectonostratigraphic reconstructions showing a time before the Scotia Sea existed, after Dalziel (1983). In panel a the region is reconstructed with some knowledge of basin opening histories in the Scotia Sea, panel b shows Dalziel's (1983) most-favourable arrangement of the Scotia Arc terranes listed with respect to the Gondwana margin they are interpreted to have formed at, and panel c shows an alternative arrangement for favourable relationships between terranes further north and south in Patagonia and the Antarctic Peninsula. 
based on the pattern of fracture zones and magnetic isochrons in the Weddell Sea show that it was initially directed northwest, that it slowed down considerably and rotated into a north-south orientation in the period 65-50 Ma, and that afterwards faster northwest divergence was re-established, rotating slowly towards a west-northwest orientation over the period 40-20 Ma. By today, South American-Antarctic plate motion is oriented almost east-west.

Subduction in the northwest Weddell Sea, beneath the South Orkney Microcontinent, is thought to have started at a Cretaceous transform fault along the sea's western continent-ocean boundary after it started to accommodate convergence as a consequence of the changing direction of South American-Antarctic plate motion (Barker et al., 1991; Eagles, 2010b). Oceanic lithosphere on the South American side of the margin was thrust far enough beneath the Antarctic Peninsula and for long enough that subduction was forced to initiate (Leng and Gurnis, 2011). The loss of South American lithosphere in this way continued until segments of the South American-Antarctic mid-ocean ridge, approaching from southeast of the collision zone, started colliding with it in Miocene times. With these collisions, new material ceased to enter the subduction zone because the trailing plate on the colliding ridge crest and the overriding plate on the subduction zone were both the Antarctic Plate (Barker et al., 1982). The ridge was organised into a series of short slow-spreading segments, making it difficult to consistently model magnetic reversal isochrons that record its progress towards collision. From where this has been done successfully, collision events seem to have occurred at progressively later times towards the northeast, until the most recent collision at $\sim 3$ Ma near $33^{\circ} \mathrm{W}, 60^{\circ} \mathrm{S}$ (Barker et al., 1984; Hamilton, 1989). Barker et al. (1984) suggested that these events may have been of fundamental importance for their complex of back-arc basins in the Scotia Sea, by removing an independently mobile element and a source of plate-boundary torque, the trench, from the plate circuit. Subduction of South American Plate lithosphere continues at the present day beneath the east Scotia Sea.

\subsubsection{Jane Basin}

Jane Basin is a narrow basin between the South Orkney Microcontinent and Jane Bank, a seafloor and basement ridge that marks the northwestern limit of fracture zone fabric and prominent magnetic reversal anomalies in the northwest Weddell Sea. Dredges from the bank returned arc-type igneous rocks (Barker et al., 1984). Its location at what would have been an active subduction zone invites an interpretation as a back-arc or intra-arc basin floored either by oceanic or arc crust. Ridge-crest-trench collision occurred off the southern end of Jane Basin in the time between chrons $6 \mathrm{C}$ and 6 (23-20 Ma), but later (chron $5 ; 10 \mathrm{Ma}$ ) off the northern end of the basin (Barker et al., 1984; Bohoyo et al., 2002; Hamilton, 1989; Livermore and Woollett, 1993). Extension in the basin, if it was subduction-related, may have ended during this period. Consistent with this, Maldonado et al (1998) correlated the seismic stratigraphies of Powell and Jane basins to suggest that Jane Basin dates from the period 18-13 Ma. Magnetic anomalies in the basin are of low amplitude and incoherent, leaving isochron interpretations equivocal (Bohoyo et al., 2002). Assuming oceanic basement and the same isostatic correction (Crough, 1983) to the depth of sedimented seafloor as in Powell, Protector and Dove basins (Eagles et al., 2006; King and Barker, 1988), Jane Basin would date from the period 27-19 Ma. On the other hand, an older age, 32-25 Ma, is suggested from heat flow estimates under the assumption that the basin fill is predominantly clay (Lawver et al., 1991).

\subsubsection{Phoenix-Antarctic system}

Seafloor spreading at a boundary between the Phoenix Plate and oceanic parts of the West Antarctic Plate initiated at chron 27 ( $61 \mathrm{Ma})$, when the Bellingshausen Plate ceased moving independently of the West Antarctic Plate (Eagles et al., 2004a, 2004b; Stock and Molnar, 1987; Wobbe et al., 2012). The parts of the Phoenix Plate that subsequently formed at this boundary are sometimes referred to as the Aluk or Drake plate. In a situation much like that in the northwest Weddell Sea, the southeast edge of the Phoenix Plate was a trench where it subducted beneath the East Antarctic Plate. With ongoing divergence away from the West Antarctic Plate on its northwest flank, and only very slow movements between the East and West Antarctic plates lasting until chron 8 (Cande et al., 2000) the Phoenix-Antarctic Ridge moved towards and into collision with the subduction zone, leading to their mutual demise. Spreading was at intermediate rates on long ridge crest segments, and so left more easily interpretable magnetic anomaly records of ridge-crest-trench collisions than in the Weddell Sea (Larter and Barker, 1991). Collisions occurred progressively later towards the northeast until, at 3.3 Ma, the northernmost three segments of the ridge ceased operating before they could collide with the trench, leaving a small remnant of the Phoenix Plate to be incorporated into the Antarctic Plate. Eagles (2004) and Eagles and Scott (in review) modelled the relative motions of the Phoenix and Antarctic plates since chron 27 using the system's extant magnetic isochrons and fracture zone orientations. The results show that the Phoenix Plate rotated about a point near its southwestern corner, perhaps in response to a strong gradient in the slab pull force set up by the variability in the mean age of the oceanic lithosphere being subducted along the trench.

\subsubsection{Bransfield Strait}

The only part of the subduction zone not to have deactivated along the western margin of the Antarctic Peninsula by ridge-crest-trench collision was at the South Shetland Trench, to the northwest of the South Shetland Islands. This part persists as a physiographic trench because it remains attached to a remnant slab of the Phoenix Plate (Larter and Barker, 1991). A narrow active extensional basin exists behind the trench in Bransfield Strait. The basin's action is related to extensional stress in the interior of the Antarctic Plate caused by continued sinking of the remnant slab. Given the setting, extension can be expected to have started upon failure of the Antarctic-Phoenix Ridge at 3.3 Ma. The lack of an oceanic floor to Bransfield Strait shows that this extension has been slight (Barker and Austin, 1998).

\subsection{Plate kinematics within the Scotia Arc}

Present-day plate motions (Fig. 1) in the Scotia Sea region have been modelled using both seismic slip vector and GPS data. Used separately or in combination, the two techniques agree on the presence of two independently-moving plates inside the Scotia Arc, the larger Scotia Plate in the west and, further east, the smaller Sandwich Plate, which diverge from one another at the north-striking east Scotia ridge along $30^{\circ} \mathrm{W}$ (Forsyth, 1975; Pelayo and Wiens, 1989; Smalley et al., 2003, 2007; Thomas et al., 2003). Smalley et al. (2007) show that the use of GPS data much reduces the uncertainties in solutions for the directions and rates of motions between these plates and their larger neighbours outside the Scotia Arc. These motions are distinct from those of the surrounding South American and Antarctic plates owing to slow transform motions on the North and South Scotia ridges, and subduction of South American lithosphere beneath the Sandwich Plate. The surface expressions of this subduction are the South Sandwich trench and islands. The overall strike of the trench is north-south, but it curves strongly westwards at its ends to meet the south and north Scotia ridges. The North Scotia Ridge behaves as a tear fault at its meeting with the trench. It accommodates downward motion of subducting parts of the South American Plate along its southern margin.

The present kinematics of the Scotia Plate may be an appropriate analogy for the last $6 \mathrm{Myr}$, during which time its long boundaries on the south and north Scotia ridges have been stable. The Sandwich Plate however grew substantially during this time and its boundary at the East Scotia Ridge lengthened southwards at $1 \mathrm{Ma}$ (Bruguier and Livermore, 2001). Given the possibility that these changes reflect or brought about some change in the driving forces on the Sandwich 
Plate, it may be inappropriate to apply its present-day motion for times much before $1 \mathrm{Ma}$.

For much earlier times, the growth of the Scotia Sea must be reconstructed on the basis of isochrons interpreted from its magnetic anomalies and structural trends, such as fracture zones preserved in the seafloor. In the west Scotia Sea, the data set of these features is well enough distributed to support a full statistical reconstruction (Eagles et al., 2005). Its neighbouring basins are all too small for such an approach to be based on a data set of meaningful size and distribution. In these instances, only qualitative statements about the uncertainty of rotation parameters can be made. These statements are nonetheless valuable, because they allow an assessment of likely relative errors in a model plate circuit by virtue of the fact that any error in a set of rotation parameters, when applied at a distance from the pole of rotation or through further rotations, can propagate to larger errors in the positions of rotated features. In the following, we describe the settings, ages, and databases for reconstruction problems in the various basins of the Scotia Sea.

\subsubsection{East Scotia Sea}

The East Scotia Sea is the site of seafloor generated by divergence of the Sandwich and Scotia (and at earlier times Central Scotia) plates. The Sandwich Plate is the arc plate to the present South Sandwich Trench, at which South American lithosphere subducts beneath the Scotia Sea. At its eastern edge, it bears the volcanic islands and seamounts of the South Sandwich Arc. Radiometric dating of rocks from the islands shows the present-day arc developed over the last 3 Myr (Baker, 1990). Further K-Ar dating on altered subduction-related rocks dredged from a submarine scarp to the east of the islands suggests that volcanism may have been underway as long ago as $32 \mathrm{Ma}$ (Barker, 1995).

To the west of the islands, the east Scotia ridge spreading centre splits the floor of the East Scotia Sea. Its presence has been known since the earliest geophysical studies of the region, which showed symmetrical magnetic anomalies arrayed each side of a seismically active $\sim 2.5-3.5 \mathrm{~km}$ deep ridge (Barker, 1972). The ridge depth varies along with evidence for geochemical variation along its length. This has been interpreted in terms of variations in the ridge's melt supply, which comes from differing mantle reservoirs that meet west of the subducted slab of South American lithosphere (Fretzdorff et al., 2002; Nicholson and Georgen, 2013). Livermore et al. (1997) present the ridge in detail, showing it to exist as a number of short segments, labelled from north to south E1-E9, between which there are short left- and right-lateral offsets. Prominent seafloor troughs emanate from these offsets, but do not fall along complementary small circle trends. The ridge crest offsets were therefore not fixed with respect to the Scotia and Sandwich plates but will have migrated, most of them southwards, during the growth of the East Scotia Sea (Bruguier and Livermore, 2001).

Identified magnetic isochrons on the flanks of the East Scotia ridge show that plate divergence there was accommodated by seafloor spreading since $17 \mathrm{Ma}$ (chron $5 \mathrm{C}$ ), and possibly a little earlier. Linear magnetic anomalies are clearly interpretable on the Scotia Plate as isochrons 5-5C, but can only be suggested from individual deep-water profiles between and to the east of the South Sandwich islands and seamounts (Barker, 1995; Schreider et al., 2011; Vanneste and Larter, 2002). Those authors suggest that the present arc is built on old backarc basin floor because it replaces an earlier arc and fore-arc that were lost to subduction erosion, the process in subduction zones by which material detaches from the overriding plate and is subsequently lost into the mantle. The dredged and dated ( 29-33 Ma; Barker, 1995) scarp in the present-day forearc may be interpreted in terms of this process continuing at present. Nerlich et al. (2013) published a set of five finite rotations about a single pole to describe the opening of the east Scotia Sea since $15 \mathrm{Ma}$, but do not detail their derivation.

\subsubsection{West Scotia Sea}

The west Scotia Sea is the site of seafloor generated in the divergence of two plates that are no longer independently active, but which make up the present-day Scotia Plate. After Eagles et al. (2005), we refer to these as the Magallanes and Central Scotia plates. The sea's western margins are at the continental rise and shelf of Tierra del Fuego and further north at the submarine Burdwood and Davis banks. Dredge samples, and internal basement reflectivity on seismic reflection profiles indicate that the banks consist of continental crust with a significant post-middle Jurassic succession similar to that of Peninsula Hardy in Tierra del Fuego (Bry et al., 2004; Macfadyen, 1933; Pandey et al., 2010). Folding and reverse faulting reveal that the banks were thrust northwards onto the Falkland Plateau in Cenozoic times and until recently (Cunningham et al., 1998). The eastern margin of the west Scotia Sea runs from Terror Rise, a 2.8-km deep bathymetric swell in the south, to South Georgia and Shag Rocks Bank in the north. Seismic reflection data crossing Terror Rise show a faulted basement surface, and an absence of the numerous typical diffractions associated with basaltic oceanic crust. It is interpreted as consisting of extended continental crust (Eagles et al., 2006). South Georgia and Shag Rocks present outcrops of unequivocally continental lithologies (Dalziel et al., 1975; Storey et al., 1977; Tyrrell, 1945). Between Terror Rise and South Georgia, magnetic reversal isochrons in deep water show that part of the eastern margin of the west Scotia Sea consists of oceanic lithosphere of the central Scotia Sea (Eagles, 2010b; Hill and Barker, 1980).

The most prominent feature of the west Scotia Sea is the northeasttrending extinct median valley known as the West Scotia Ridge. The median valley consists of seven main segments, labelled W1-W7, which are defined by a number of long and short right-lateral fossil transform offsets (Eagles et al., 2005). Many of the transforms created fracture zone traces in the neighbouring seafloor. Magnetic anomaly profiles crossing the west Scotia Sea are confidently interpretable to show isochrons 8-3 (26-5.5 Ma) on both plates in the spreading corridors created by the actions of segments W1-W5 (Barker and Burrell, 1977; Eagles et al., 2005; LaBrecque and Rabinowitz, 1977; Livermore et al., 1994; Lodolo et al., 2006). These studies also make isolated identifications of isochrons 9 and 10 on one flank or the other over deep water at the extremes of some of these corridors. Interpretations of isochrons 11 and 12 have also been made from anomalies west of Terror Rise, without conjugate identifications off Tierra del Fuego (e.g. Schreider et al., 2012). These asymmetric identifications suggest that systematic surveying to the west of Terror Rise and at the foot of the eastern Fuegian shelf would likely reveal evidence for a complex pattern of spreading prior to $26 \mathrm{Ma}$ (Barker and Burrell, 1977). Further northwards, the oldest paired isochrons become younger until 5C in the corridor about W7. The West Scotia Ridge seems therefore to have propagated northwards. All models of these magnetic anomalies show that spreading started in the west Scotia Sea at intermediate rates ( $\sim 26 \mathrm{~mm} / \mathrm{yr}$ half rate), which later dropped to slow $(\sim 12 \mathrm{~mm} / \mathrm{yr})$ at around chron $5 \mathrm{C}$.

Burrell (1983) and Eagles et al. (2005) modelled the plate rotations that would have given rise to the observed distribution of magnetic isochrons. Eagles et al. (2005) supplemented the constraints using the shapes of fracture zones. Their results confirm the deceleration of spreading rates around chron $5 \mathrm{C}$, by which the Magallanes and Central Scotia plates started to diverge at rates very similar to the divergence of the enclosing South American and Antarctic plates. They suggested that this shows the Magallanes and Central Scotia plates moved very slowly with respect to South America and Antarctica after $17 \mathrm{Ma}$, but that at earlier times the Central Scotia Plate moved more rapidly eastwards with respect to Antarctica as a consequence of trench migration at its eastern margin. This is consistent with the observation that easterly trench motion has been accommodated by back-arc spreading in the east Scotia Sea since chron 5C (Barker, 1972; Vanneste and Larter, 2002).

\subsubsection{Protector Basin}

Protector Basin is the area of deep seafloor that lies between Terror Rise and Pirie Bank. Pirie Bank is a tectonically-stretched microcontinent. 
Seismic reflection profiles show that its upper parts are textured by numerous normal faults and dredging returned an assortment of rock types and ages that is similar to that cropping out in Tierra del Fuego (Galindo-Zaldívar et al., 2006; Schenke and Udintsev, 2009; Udintsev et al., 2012). The seismic data quality is insufficient to permit an estimate of tectonic extension factors for the bank.

Protector Basin hosts a modest fossil median valley, buried beneath approximately $1 \mathrm{~km}$ of sediments (Galindo-Zaldívar et al., 2006). Magnetic anomalies over the basin floor reveal a central normalpolarity isochron centred on the median valley, and two further narrow normal-polarity isochrons separated from one another by a wide region of reversed polarity. The anomalies strike north and reveal that the basin opened along an east-west azimuth. Hill and Barker (1980) modelled the anomalies to interpret the isochrons as $5 \mathrm{C}$ to 5 (Miocene), after noting that their reconstruction of the west Scotia Sea required extra east-west extension to fit their southern identifications of anomaly 8. Although this anomaly interpretation has since been reproduced and used widely (Galindo-Zaldívar et al., 2006; Maldonado et al., 2003; Vérard et al., 2012), it is neither a requirement of the short magnetic profiles nor of the better-constrained modern understanding of anomaly 8's distribution in the west Scotia Sea. Eagles et al. (2006) show that the isostatically-corrected basement depth suggests a basin age near that of the Eocene-Oligocene boundary. They noted that the basement reflector is rugged, suggesting slow spreading rates. With this further constraint, only two parts of the magnetic reversal timescale can reproduce the wide reverse-polarity isochron in the basin floor: those for chrons 21-20, and those for chrons 13-11. Heat flow calculations from sediment temperature gradients support the younger of these two determinations, suggesting an age range of 28-25 Ma (Barker et al., 2013).

\subsubsection{Dove Basin}

Dove Basin lies east of Pirie Bank, which it separates from another bathymetric high with a broad central magnetic anomaly, Bruce Bank. Like Pirie Bank and Terror Rise, Bruce Bank is likely to be a tectonically-extended microcontinent. Rocks of continental lithologies have been dredged from the bank (Udintsev et al., 2012). Seismic reflection data (Hernández-Molina et al., 2007) reveal a diffraction-poor basement surface that is cut by normal faults, but do not permit estimation of crustal stretching factors. Palynological analysis of a piston core sample shows that the bank subsided from depths of $<1000 \mathrm{~m}$ since Paleogene times (Mao and Mohr, 1995).

An elongate north-northeast-striking seamount occupies the central segment of Dove Basin's axis. The seamount is associated with a strong reverse-polarity magnetic anomaly that differs from the normal-polarity anomalies elsewhere on the axis (Eagles et al., 2006). For this reason, it is suggested that the seamount post-dates seafloor spreading in the basin and represents evacuation of magma from the post-spreading mantle, as at the extinct Phoenix-Antarctic Ridge (Haase et al., 2011). Away from the seamount, the regularly-spaced magnetic anomalies of Dove Basin show a sequence of four polarity reversals that can be modelled to represent isochrons in multiple parts of the magnetic reversal timescale. Their strike suggests the basin opened along a west-northwest azimuth. The seafloor in the basin is among the deepest in the Scotia Sea, exceeding $4 \mathrm{~km}$ in places. Based on this depth, after isostatic adjustment for around $1 \mathrm{~km}$ of sediment fill, and assuming that seafloor spreading there would not have occurred simultaneously with spreading elsewhere in the Scotia Sea, Eagles et al. (2006) presented a model of magnetic anomaly isochrons 18-15 (41-35 Ma) for the basin. Consistent with this, Barker et al. (2013) modelled heat flow values near the basin margins to suggest basement ages in the range 43-42 Ma.

\subsubsection{Scan Basin}

Scan Basin (also referred to as Discovery or Bruce-Discovery basin) lies between Bruce Bank and Discovery Bank. To the north, it borders the older (17-10 Ma) parts of the East Scotia Sea. The transition between the two basins appears smooth in gravity, bathymetry and seismic data (Maldonado et al., 2003). Dredges on Discovery Bank returned arc-tholeiites with South Sandwich affinities, and K-Ar ages of 20-12 Ma, suggesting it may be part of the ancestral island arc to the South Sandwich islands (Barker et al., 1982). On the other hand, the southern part of the bank at least may consist partially of older continental crust because it is the site of a magnetic anomaly similar to that on the Fuegian shelf (Eagles et al., 2006).

The sediment fill of Scan Basin is of variable thickness (1-2 s TWT), thickening towards the south and east (Hernández-Molina et al., 2007). The basin floor is relatively smooth. There is little sign of an extinct midocean ridge axis in either the bathymetry or gravity data from the basin. Magnetic anomalies over the basin are subdued and form no obvious lineations. Even after isostatic adjustment for its sediment fill, the basin is considerably shallower, and so may be younger, than both Protector and Dove basins. This would be consistent with a back-arc interpretation of Scan Basin that sees it opening alongside arc volcanism at Discovery Bank. Heat flow calculated from sediment temperature gradients in the basin's northwest corner suggests however that it may date from 30.2 Ma (Barker et al., 2013).

\subsubsection{Powell Basin}

Powell Basin lies within the South Scotia Ridge, separating continental crust of the Antarctic Peninsula on its western side from the South Orkney Microcontinent. This location makes the basin important for regional reconstructions because of its potential to link plate tectonics in the interior of the Scotia Sea with the surrounding plate circuit. Powell Basin's northern margin is a neck in the South Scotia Ridge, which is dissected by a deep narrow seismically-active trough (Galindo-Zaldívar et al., 1996). To the south, the basin is open to the Weddell Sea. Seismic data over the basin margins reveal clear signs of continental extension, with normal faults and rotated fault blocks, and possible seaward dipping reflector sequences hinting at accompanying volcanism (King and Barker, 1988). Dredge samples from the margin of the South Orkney Microcontinent include alkali basalts with a wide spread of K-Ar ages (Barber et al., 1991). The oldest, at 49-48 Ma, suggests that the basin may have started to open by continental extension in Eocene times. The youngest have been interpreted in terms of a slab window opening beneath the basin following ridge-crest-trench collisions in the northwest Weddell Sea (Eagles et al., 2009a). Prominent high-amplitude normal-polarity magnetic anomalies traverse the South Orkney Microcontinent and opposing Antarctic Peninsula from east to west. On the peninsula side this feature is known as the Pacific Margin Anomaly, and is thought to betray the presence of a Cretaceous subduction-related batholith (Ferraccioli et al., 2006; Garrett, 1990).

Powell Basin is characterised by a relatively smooth bathymetry, which after correction for sediment thickness of 2-3 s TWT suggests an oceanic basement with ages in the range 29-23 Ma (King and Barker, 1988). The buried median valley of an extinct spreading centre is evident in seismic reflection data and a modest gravity low (Coren et al., 1997; King et al., 1997). Magnetic anomalies over the basin are of low amplitude, despite which an overall pattern of northweststriking lineations is discernible. This magnetic character has been attributed to thick sediment cover on a northwest-striking mid-ocean ridge during the spreading phase, such that the upper oceanic crust cooled slowly and underwent heavy hydrothermal alteration, reducing its effectiveness as a magnetic carrier (Eagles and Livermore, 2002). The anomalies show no distinctive coherent phase characteristics, such that differing sets of isochrons have been interpreted in them (Coren et al., 1997; Eagles and Livermore, 2002). Both studies nonetheless suggest that a main phase of spreading coincided with the basement depthderived age. The azimuth of seafloor spreading in the basin is not well constrained except by reference to its east-northeast trending northern margin, whose steepness suggests that it acted as a sheared margin to the developing basin floor. Euler rotations to describe the opening of the basin were published by Garrett et al. (1986), to unite the magnetic 
anomaly on the South Orkney Microcontinent with the Pacific Margin Anomaly, and Eagles and Livermore (2002) to align the conjugate magnetic isochrons of the basin floor.

\subsubsection{Central Scotia Sea}

The central Scotia Sea is the deep-water area between the west and east Scotia Sea basins. Pirie and Bruce banks and the intervening Dove Basin lie at its southern edge. To the north, it borders the North Scotia Ridge at Shag Rocks and the South Georgia microcontinent. The central Scotia Sea is defined further by the presence of prominent east-striking magnetic anomalies, which have been interpreted as isochrons since their first recording (Barker, 1970, 1972). The unusual north-directed plate divergence the isochrons imply was suggested to have occurred in a Cretaceous, or Oligocene-Miocene, or Miocene back-arc basin (DeWit, 1977; Hill and Barker, 1980). The younger ages are supported by models of the magnetic anomalies as isochrons from those periods, and by the shallow $(2.6-3.5 \mathrm{~km})$ seafloor. The model represents part of a pathway for South Georgia to have departed an early position close to Tierra del Fuego (Barker et al., 1991). For these reasons, the idea of Miocene seafloor in the central Scotia Sea remains a widelydepicted one (e.g. Brown et al., 2006; Müller et al., 2008). Lawver et al. (1992), Vérard et al. (2012) and Nerlich et al. (2013) place the opening of a Miocene central Scotia Sea in plate kinematic context, although only Nerlich et al. (2013) report their rotations.

Livermore et al. (1994), Eagles et al. (2005, 2006) and Eagles (2010b) highlight a number of contradictory observations to this scenario. The basin floor lacks the fossil mid-ocean ridge that its slow spreading rate ought to have given rise to. Although shallow, the seafloor actually deepens towards the basin's median line. There is no evidence for the mature subduction zone in the Falkland Trough that would be required to provide the driving mechanism for northdirected plate divergence. There is no evidence for the Miocene arc volcanism on South Georgia that must have accompanied this subduction. Sediment temperature gradients, measured at multiple widelyseparated sites over multi-year timescales, are consistently far shallower than should exist in equilibrium with Miocene oceanic basement (Barker and Lawver, 2000; Zlotnicki et al., 1980).

New modelling of the sediment temperature gradient and of isochrons in the magnetic anomalies leads to the conclusion that the central Scotia basement is instead of Mesozoic age (Eagles, 2010b). Possible explanations for the basin's shallow seafloor, if it is so old, have yet to be studied but are suggested to be related to subduction beneath it. Eagles (2010a,b) interprets the magnetic reversal isochrons in the central Scotia Sea as conjugates to the sequence in the Weddell Sea, and South Georgia, Tierra del Fuego, and the intervening North Scotia Ridge as the antecedent extended continental margin. In this view, South Georgia's geological similarities with Tierra del Fuego reflect their shared experience of continental extension that led to Gondwana breakup. In contrast, Lawver et al. (2011) and Dalziel et al. (2013a) depict Cretaceous seafloor, and combine it with suggestions of $\sim 500-600 \mathrm{~km}$ of Eocene-Oligocene or mid-Cretaceous subduction beneath South Georgia in order to remove the island from a tectonostratigraphically-advocated position close to Tierra del Fuego. Neither of these studies lists its rotations.

\section{Margins of the Central Scotia Sea}

A Cretaceous central Scotia Sea would be older than all of its presentday boundaries except that with South Georgia. Data from Polarstern cruise ANTXXII/4 in 2005 allow us to focus on its western boundary, to which the west Scotia Sea would have accreted during plate divergence. A combination of swath bathymetry and shipboard three-component and helicopter-towed magnetic data were collected systematically in 2005 (Fig. 3). In the bathymetric data set, smooth deep (3.5-4.6 km) ocean floor of the central Scotia Sea continues as far west as $44^{\circ} \mathrm{W}$, $56.3^{\circ} \mathrm{S}$, in an area named Polarstern Basin. To the west of this basin, north-northeast-trending abyssal hill fabric characterises the shallower floor of the west Scotia Sea. This border between the two trends southeast overall, following three south-striking and two east-striking segments. The south-striking segments coincide with identifications of magnetic isochrons 6C, 6B and 6A (Eagles et al., 2005). Further north, the boundary between the west and central Scotia seas is characterised by the Pirie Province, a $100 \times 130 \mathrm{~km}$ wide egg-shaped area of raised (1.9-3.6 km deep) seafloor. The province's northwest-facing edge is a smooth sediment-draped slope at whose foot magnetic isochron 6 in the west Scotia Sea is identified (Eagles et al., 2005). The province's southern and eastern edges are scarps facing the Polarstern Basin and central Scotia Sea. East-striking magnetic anomalies of the central Scotia Sea continue up to the scarps.

The seafloor over the Pirie Province itself is rugged, characterised by a pattern of isolated circular seamounts with strong normal and reverse-polarity magnetic anomalies, and north-northeast- and eaststriking abyssal hills that magnetic anomalies do not always strongly align with. The new bathymetric and magnetic anomaly data, together with those of Dalziel et al. (2013b; suppl. material) show the unconjugated crossings of 'west Scotia' magnetic isochrons 8 and 6B by Eagles et al. (2005) over and to the northeast of the province to have been interpreted in error. Consistent with the lack of conjugate identifications off Davis Bank, the crossings are instead of uncorrelated point anomalies and the signals of volcanic ridges and scarps, and so do not constrain the age of the Pirie Province. Instead, recent dredging of the province's southern scarp and a ridge south of it in the floor of the Polarstern Basin returned a great quantity of volcaniclastic material, which yielded Ar-Ar ages of $11 \mathrm{Ma}$ and 28.5 Ma (Dalziel et al., 2013b; Pearce et al., submitted for publication). The 28.5 Ma date suggests that at least some of the Pirie Province's basement was already in existence at the onset of seafloor spreading in the west Scotia Sea. Similarly, the progression of oldest magnetic reversal isochrons from $6 \mathrm{C}$ south of the Pirie Province to 6 on its northwest edge can be interpreted to portray northwards propagation of the West Scotia Ridge around the edge of a pre-existing feature at 23.5-19.5 Ma. Hints of easterly trends in the longer-wavelength magnetic anomalies over the province suggest that it may even be built on basement of the central Scotia Sea.

In the absence of comparable data, the southern and eastern margins of the central Scotia Sea remain less well understood. A Cretaceous central Scotia Sea would have experienced transform motions along its southern margin during the opening of Dove and Protector basins at $\sim 41-30 \mathrm{Ma}$. There are no strong indications of the precise location or nature of such a transform zone to the south of the east-striking magnetic lineations. Seismic reflection data crossing the area north of Pirie Bank reveal a moderately deep ( $5 \mathrm{~s}$ TWT) basement covered by a thick ( $>1 \mathrm{~s}$ TWT) sedimentary cover, within which the temperature gradient implies a basement age of 35-34 Ma (Barker et al., 2013). Gravity data hint at west-northwest- and east-northeast-trending structures in the basement. Further north, in the swath bathymetry data of Fig. 3, a rugged sigmoidal high on one of the stepped parts of the boundary with the west Scotia Sea might be interpreted in terms of transpressional uplift at a restraining bend or step on this southern boundary.

\section{New Euler rotations for basin reconstructions}

\subsection{East Scotia Sea}

The present-day relative motion of the Sandwich and Scotia plates is not a good guide to their relative motion in the geological past. Smalley et al.'s (2007) and Thomas et al.'s (2003) rotations for present motions of this plate pair are similar to each other, but an extrapolation of either for a period of $6 \mathrm{Myr}$ fails to reconstruct the conjugate pair of magnetic isochrons $3 \mathrm{~A}$ on those plates. The inapplicability of the present-day pole to this task is consistent with evidence for post-3A changes in the East Scotia Sea, for example the southward propagation of the East Scotia 

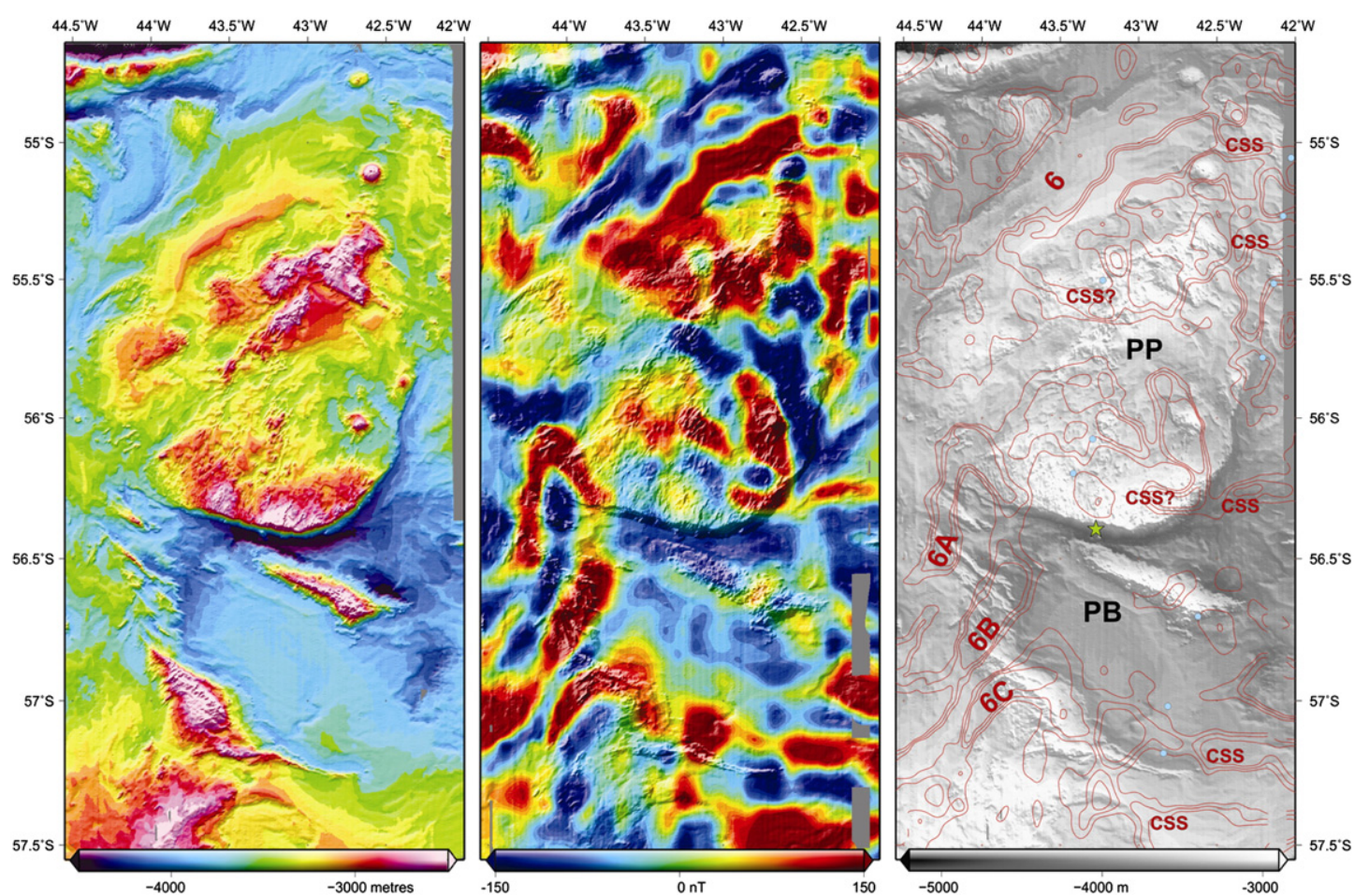

Fig. 3. The boundary between the central and west Scotia Sea basins as seen in swath bathymetry (left and right) and combined helicopter- and ship-derived magnetic total field data (centre). Right-hand panel, interpretation shows selected contours of the magnetic data set overlying the swath bathymetry data. PB: Polarstern Basin, PP: Pirie Province, 6, 6A, 6B and 6C: Identified magnetic isochrons of the West Scotia Sea, CSS: east-striking magnetic isochrons of the central Scotia Sea. Blue discs: erroneous 'west Scotia' isochron picks of Eagles et al. (2005). Green star: approximate location of dredged 28.5 Ma volcanic rocks (Dalziel et al., 2013b).

Ridge in the last million years (Bruguier and Livermore, 2001), which hint at changes in the balance of driving forces.

Fig. 4 presents the results of visual-fit modelling for Euler rotations to reconstruct the east Scotia Sea at chrons 3A and 5, and at times prior to the onset of back-arc extension. Magnetic isochrons were digitised from the map presented by Vanneste and Larter (2002). The Sandwich Plate isochrons were rotated towards their Scotia Plate conjugates with the aim of aligning their strikes and the locations of pseudofaults that interrupt them. We improved the rotations by trial and error. The latitudes of the rotation poles should be viewed as poorly-estimated in view of the nearly north-south strike of the

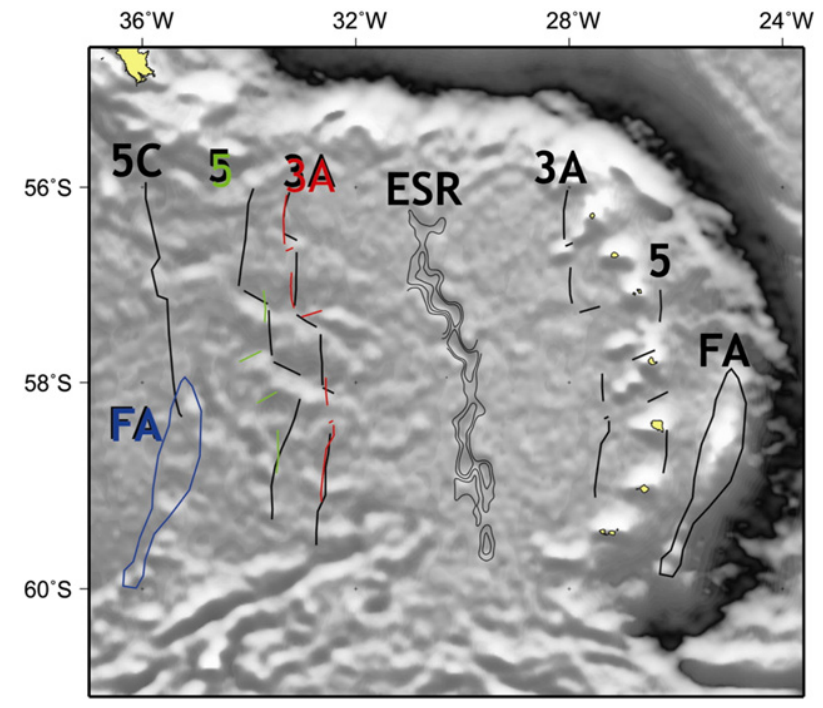

Fig. 4. Visual fits modelling for rotations to reconstruct the east Scotia Sea. ESR: East Scotia Ridge (highlighted by selected gravity contours), FA: Fore-arc high. Numbers: reversal isochron numbers. Features rotated from the Sandwich plate are shown in colour after rotations. isochrons and relatively short (300 km) boundary length. For a full pre-divergence reconstruction of the East Scotia Sea, the stage rotation for the period $3 \mathrm{~A}-5$ is extrapolated backwards so that the edge of the fore-arc high on the Sandwich Plate, which may date back to 33-29 Ma (Barker, 1995; Livermore et al., 1994), coincides with the $5 \mathrm{C}$ isochron on the Scotia Plate.

\subsection{The earliest west Scotia Sea and the Scan, Dove and Protector Basins}

Distinctive $100-\mathrm{km}$ wide normal-polarity magnetic anomalies cross Tierra del Fuego, Terror Rise, Pirie, Bruce and Discovery banks from west to east. The anomaly in Tierra del Fuego coincides with outcrops of a Cretaceous-aged granitic batholith. Closure of the west Scotia Sea, Protector, Dove and Scan basins would juxtapose all of these anomalies to form a continuous belt, perhaps representing a continuous batholith (Eagles et al., 2006). Consistent with the idea of geological continuity across the closed basins, the dredged assortments of rocks on Pirie and Bruce banks resemble those cropping out in Tierra del Fuego (Schenke and Udintsev, 2009; Udintsev et al., 2012). Nerlich et al. (2013) presented rotations for alignment of the bathymetric outlines of Bruce, Discovery and Pirie banks, Terror Rise, and southeastern Tierra del Fuego. The rotations were not designed to reconstruct the magnetic anomalies.

The various banks and rises are reconstructed in two ways in Fig. 5 using the complementary constraints that, prior to their separation, their opposing margins should have been united and that they should have hosted a wide through-going magnetic anomaly. The margins of the banks are interpreted from the satellite gravity anomalies of Sandwell and Smith (2009), and the magnetic anomaly data are from the reduced to the pole grid of Eagles et al. (2005). The reconstructions are intended to convey the effects of uncertainty in the positions of the Euler rotation poles, which are very large owing to the short lengths of the margins and narrow $(100 \mathrm{~km})$ widths of the magnetic anomalies being reconstructed. One reconstruction uses a set of rotations about nearby poles, the other uses rotations about more distant poles. Whilst 
$68^{\circ} \mathrm{W}$
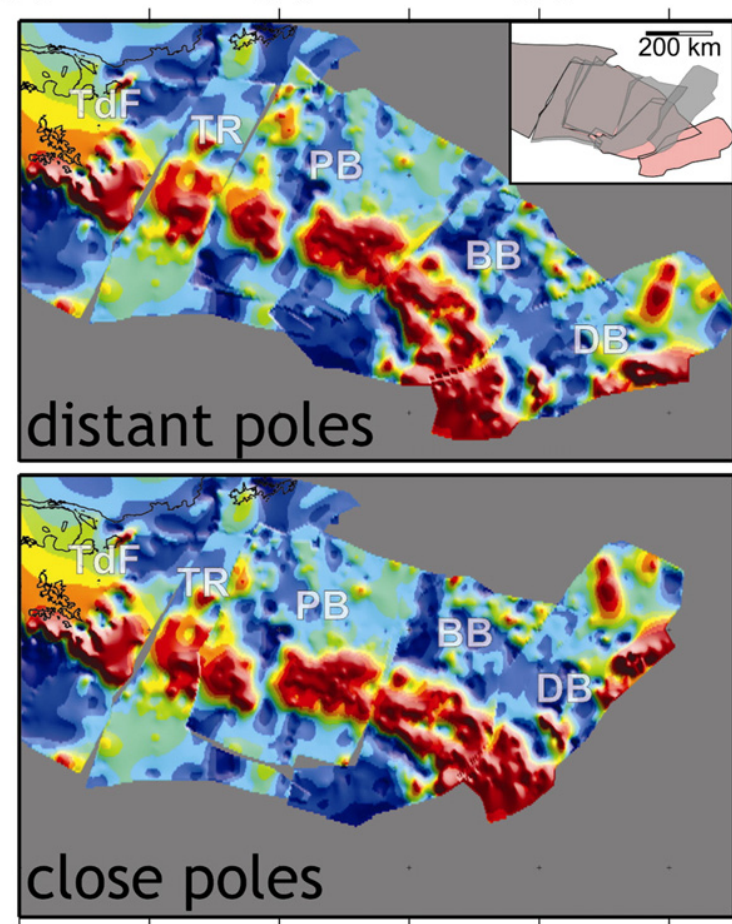

$68^{\circ} \mathrm{W}$ $64^{\circ} \mathrm{W}$ $56^{\circ} \mathrm{S}$

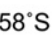

Fig. 5. Reconstructions of small basins from visual fits of magnetic anomalies of Tierra del Fuego (TdF), Terror Rise (TR), Pirie Bank (PB), Bruce Bank (BB) and Discovery Bank (DB). Top: a reconstruction using rotations about distant Euler poles for Dove and Protector basins. Bottom: a reconstruction using poles much closer to the basins. Inset: reconstruction comparison with the gravity-defined outlines of the banks and rises used. Pink: distant poles, grey: close poles.

the alignment of the anomalies across the basins is similar in each case, the curvature of the reconstructed anomaly belt is stronger when distant rotation poles are used. The reconstructions thus imply quite different locations for the extremes of the belt, which will have different implications for their application in regional tectonic reconstructions. At this stage, there is no reason to expect any particular curvature for the magnetic anomaly's reconstructed source body, and therefore no reason to prefer one set of rotation parameters over the others.

\section{Fitting the Scotia Sea into the regional plate circuit}

As outlined above, our approach requires the reconstructed Scotia Sea floor to fit inside the encircling major plate reconstruction without violating any plate kinematic constraints known from the regional geological history. In producing and assessing the fit, we leave the major plate reconstruction fixed because it is based on longer paleo-plate boundaries than are preserved within the Scotia Sea and therefore has smaller uncertainties. Using a similar approach, Eagles et al. (2005) investigated how opening of the west Scotia Sea might have been accommodated between the enclosing South American and Antarctic plates. They noted that fixing the Central Scotia Plate to the Antarctic Plate after the opening of Powell Basin could reproduce well-known convergence on the North Scotia Ridge and in Tierra del Fuego (Bry et al., 2004; Cunningham et al., 1998; Kraemer, 2003), but because this convergence is not well dated or quantified they could not fully rule out the possibility of accompanying convergent motion on the South Scotia Ridge, for which interpretation there are hints in seismic profiles (Galindo-Zaldivar et al., 1996). At earlier times, they showed that Powell Basin could have opened between the central Scotia and Antarctic plates if the Magallanes and South American plates were fixed or moving slowly with respect to each other at the same time.
To undertake a similar analysis for the floor of the entire Scotia Sea and its surrounding plates, here we make use of the following assumptions from consideration of the geometries of plates and plate boundaries:

(i) that at any time, the floor of the Scotia Sea immediately behind the South Sandwich Trench was occupied by a single arc plate that did not undergo significant internal deformation, and

(ii) that the reconstructed Scotia Sea floor should not overlap or underlap with any of the major plates surrounding it except where there is independent evidence for extension or convergence between them in the region of overlap or underlap.

To apply the first of these assumptions, we adopt the interpretations of (i) a Cretaceous central Scotia Sea, of (ii) the Jane and Scan basins being contiguous and contemporary with the oldest parts of the east Scotia Sea, and of (iii) no plate motion on the South Scotia Ridge prior to or during the opening of Powell Basin. The requirements of the second assumption are met by adjusting the shape and position of the reconstructed Scotia Sea within the surrounding major plate reconstruction. The adjustments are applied using three separate classes of rotations, details of whose derivations we describe in the next section. The first class describes relative motion of the Scotia and Antarctic plates along the South Scotia Ridge at times after Powell Basin opened. The second class describes their relative motion by opening of Powell Basin. The final class of rotations describes possible shapes and attitudes for the arc plate brought about by the various rotations for opening of Dove and Protector basins (Fig. 5).

The relative and combined uncertainties of the rotations in any regional model of the Scotia Sea will mostly be large, unavoidably owing to the often-small magnitudes of movements they are designed to depict or to the small data sets they are built from (Table 1). Unlike other models of the region, however, ours is built with a strict adherence to geometric constraints concerning the tectonics of plates and their boundaries, as made explicit by its depiction with gridded data, so that we can be confident its uncertainties are dominated by the uncertainties in its constituent rotations. Because of our plate circuit's construction, the sum of its reconstruction uncertainties tends to increase with age, and towards the plate boundary in Tierra del Fuego. This boundary shows a history of convergent and divergent plate motions as a consequence of the addition of rotations in our chosen parameter set. Past motions at this continental plate boundary zone cannot be quantified in the same way as for the complex of basins in the Scotia Sea, so that their uncertainties are likely to be of a similar magnitude to those arising from error propagation. Despite this, we can be reasonably confident of the history of the sense of plate motion from the outcrop geology, and this can be shown to have had both convergent and divergent phases at similar times to those produced in our model (Barbeau et al., 2009; Ghiglione et al., 2008; Gombosi et al., 2009; Klepeis and Austin, 1997; Klepeis et al., 2010; Kraemer, 2003). As such, in spite of its large uncertainties, the model approaches a self-consistent depiction of the tectonic history of the Scotia Sea.

Beyond this, our model like any other is subject to caveats related to the variety of age interpretations for the basins of the Scotia Sea, and to incomplete knowledge of the timing and nature of movements on its margins with the surrounding South American and Antarctic plates. Within these less easily quantifiable parameters it may be possible to meet the constraints of a single rigid arc plate and explicable overlaps and underlaps in ways other than we show. The model we present must therefore be viewed as plausible because of its self-consistency, but not definitive.

\section{Tectonic reconstructions of the Scotia Sea}

This section presents the tectonic development of the Scotia Sea region according to our model as a set of reconstructions in forward order, starting at $50 \mathrm{Ma}$ and finishing at $6 \mathrm{Ma}$, via seven intermediate steps at 
Table 1

Finite rotations used for the reconstructions for Figs. 6-15. All rotations are right-handed.

\begin{tabular}{|c|c|c|c|c|c|c|c|c|c|}
\hline$\#$ & Period, $\mathrm{Ma}^{\mathrm{a}}$ & Moving & Fixed & Latitude & Longitude & Angle & Source & Note & Relative certainty \\
\hline 1 & $6-0$ & NAZ & ANT & -49.84 & 80.36 & 3.62 & Tebbens and Cande (1997) & Interpolated for $6 \mathrm{Ma}$ & Medium \\
\hline 2 & $6-0$ & PHO & ANT & -69.16 & -92.32 & 3.01 & Eagles and Scott (in review) & Chron 3 & High \\
\hline 3 & $6-0$ & SCO & ANT & -85.57 & 273.23 & -0.84 & Smalley et al. (2007) & South Scotia Ridge. extrapolated to $6 \mathrm{Myr}$ & Medium \\
\hline 4 & $6-0$ & ELE & ANT & -85.57 & 273.23 & 0.42 & Smalley et al. (2007) & Half angle of \#3. & Low \\
\hline 5 & $6-0$ & SAM & ANT & 81.63 & -17.17 & 1.58 & Eagles et al. (in preparation) & Chron $3 \mathrm{~A}$ & High \\
\hline 6 & $6-0$ & AFR & SAM & 5.47 & -37.98 & 1.53 & Pérez-Díaz and Eagles (submitted for publication) & Interpolated for $6 \mathrm{Ma}$ & Medium \\
\hline 7 & $6-0$ & SAN & SCO & -83.69 & -26.55 & 6.33 & Fig. 3 & & Low \\
\hline 8 & $6-0$ & SSH & ANT & 61.51 & 46.60 & 0.80 & This paper & Visual fit of shelves & Low \\
\hline 9 & $10-0$ & NAZ & ANT & -52.40 & 80.56 & 6.63 & Tebbens and Cande (1997) & Interpolated for $10 \mathrm{Ma}$ & Low \\
\hline 10 & $10-0$ & PHO & ANT & -69.44 & -89.76 & 10.47 & Eagles and Scott (in review) & Chron 5 & High \\
\hline 11 & $10-0$ & MAG & CSS & 6.21 & -27.89 & 0.97 & Eagles et al. (2005) & Chron 5 & Medium \\
\hline 12 & $10-0$ & SAN & CSS & -80.78 & -29.79 & 10.04 & Fig. 3 & & Low \\
\hline 13 & $10-0$ & SAM & AFR & 54.86 & -38.35 & 2.82 & Pérez-Díaz and Eagles (submitted for publication) & Chron 5 & High \\
\hline 14 & $10-0$ & CSS & ANT & 70.56 & 140.42 & 2.08 & Fig. 7 & Interpolated between \#3 and \#21 & Low \\
\hline 15 & $10-0$ & SAM & ANT & -77.92 & 156.03 & -2.79 & Eagles et al. (in preparation) & Chron 5 & High \\
\hline 16 & $17-0$ & SAN & CSS & -83.69 & -26.57 & 12.50 & Fig. 3 & & Low \\
\hline 17 & $17-0$ & SAM & AFR & 54.39 & -35.46 & 5.80 & Pérez-Díaz and Eagles (submitted for publication) & Chron 5C & High \\
\hline 18 & $17-0$ & SAM & ANT & -78.57 & 158.35 & -5.28 & Eagles et al. (in preparation) & Chron $5 \mathrm{C}$ & High \\
\hline 19 & $17-0$ & PHO & ANT & -68.63 & -89.43 & 26.57 & Eagles and Scott (in review) & Interpolated for $17 \mathrm{Ma}$ & Medium \\
\hline 20 & $17-0$ & MAG & CSS & 31.71 & -23.37 & 2.16 & Eagles et al. (2005) & Chron $5 \mathrm{C}$ & Medium \\
\hline 21 & $17-0$ & CSS & ANT & 69.64 & 140.95 & 2.28 & Fig. 8 & Avoid MAGPHO overlap & Low \\
\hline 22 & $18.5-0$ & MAG & CSS & 35.57 & -23.53 & 2.88 & Eagles et al. (2005) & Interpolated to fit Shag Rocks-South Georgia & Low \\
\hline 23 & $20-0$ & SAM & AFR & 54.29 & -34.79 & 7.15 & Pérez-Díaz and Eagles (submitted for publication) & Chron 6 & High \\
\hline 24 & $20-0$ & MAG & CSS & 37.89 & -23.64 & 3.60 & Eagles et al. (2005) & Chron 6 & Medium \\
\hline 25 & $20-0$ & PHO & ANT & -68.50 & -89.86 & 32.65 & Eagles and Scott (in review) & Chron 6 & High \\
\hline 26 & $20-0$ & SAM & ANT & -78.54 & 161.26 & -5.78 & Eagles et al. (in preparation) & Chron 6 & High \\
\hline 27 & $20-0$ & CSS & ANT & 68.52 & 141.53 & 2.57 & Fig. 9 & Avoid MAGPHO overlap & Low \\
\hline 28 & $21.5-0$ & MAG & CSS & 34.34 & -25.95 & 4.29 & Eagles et al. (2005) & Interpolated for Davis Bank-Pirie Complex fit & Low \\
\hline 29 & $26-0$ & MAG & CSS & 17.21 & -32.12 & 6.64 & Eagles et al. (2005) & Chron 8 & Medium \\
\hline 30 & $26-0$ & SAM & ANT & -71.51 & 167.44 & -7.03 & Eagles et al. (in preparation) & Chron 8 & High \\
\hline 31 & $26-0$ & SAM & AFR & 54.42 & -33.51 & 10.43 & Pérez-Díaz and Eagles (submitted for publication) & Chron 8 & High \\
\hline 32 & $26-0$ & CSS & ANT & 52.92 & 122.35 & 3.0 & Fig. 10 & Powell Basin & Low \\
\hline 33 & $30-0$ & SAM & AFR & 55.09 & -33.20 & 11.75 & Pérez-Díaz and Eagles (submitted for publication) & Interpolated for $30 \mathrm{Ma}$ & Medium \\
\hline 34 & $30-0$ & SAM & ANT & -72.15 & 172.69 & -8.63 & Eagles et al. (in preparation) & Interpolated for $30 \mathrm{Ma}$ & Medium \\
\hline 35 & $30-0$ & MAG & CSS & 5.18 & -38.18 & 9.1 & Fig. 5 & Tierra del Fuego to Terror Rise & Medium \\
\hline 36 & $30-0$ & WAN & ANT & -18.15 & -17.85 & 0.35 & Cande et al. (2000) & Interpolated for $30 \mathrm{Ma}$ & Low \\
\hline 37 & $30-0$ & CSS & ANT & 49.50 & 124.60 & 7.93 & Fig. 11 & Powell Basin & Low \\
\hline 38 & $33-0$ & SAM & AFR & 55.62 & -32.94 & 13.07 & Pérez-Díaz and Eagles (submitted for publication) & Chron 13 & High \\
\hline 39 & $33-0$ & SAM & ANT & -72.46 & 176.00 & -9.99 & Eagles et al. (in preparation) & Chron 13 & High \\
\hline 40 & $33-0$ & WAN & ANT & -18.15 & -17.85 & 0.70 & Cande et al. (2000) & Chron 13 & Low \\
\hline 41 & $33-30$ & MAG & CSS & 71.21 & 133.42 & 8.31 & Fig. 5 & Protector Basin & Low \\
\hline 42 & $33-0$ & CSS & ANT & -3.38 & 115.25 & 2.60 & Fig. 12 & Powell Basin & Low \\
\hline 43 & $41-0$ & SAM & AFR & 57.14 & -32.10 & 16.56 & Pérez-Díaz and Eagles (submitted for publication) & Interpolated for $41 \mathrm{Ma}$ & Low \\
\hline 44 & $41-0$ & SAM & ANT & -74.92 & -170.11 & -14.83 & Eagles et al. (in preparation) & Interpolated for $41 \mathrm{Ma}$ & Low \\
\hline 45 & $41-0$ & WAN & ANT & -18.15 & -17.85 & 1.50 & Cande and Stock (2004) & & Low \\
\hline 46 & $41-35$ & MAG & CSS & 67.35 & 132.54 & 11.82 & Fig. 5 & Dove Basin & Low \\
\hline 47 & $41-0$ & CSS & ANT & -82.09 & 52.90 & 5.00 & Fig. 5 & Powell Basin & Low \\
\hline 48 & $50-0$ & SAM & AFR & 60.27 & -32.12 & 20.05 & Pérez-Díaz and Eagles (submitted for publication) & Interpolated for $50 \mathrm{Ma}$ & Low \\
\hline 49 & $50-0$ & SAM & ANT & -76.50 & -159.89 & -17.30 & Eagles et al. (in preparation) & Interpolated for $50 \mathrm{Ma}$ & Low \\
\hline 50 & $50-0$ & CSS & ANT & -82.09 & 52.90 & 5.38 & Fig. 12 & Powell Basin & Low \\
\hline
\end{tabular}

a Rotations are generally calculated for given magnetic isochron dates, which vary between published timescales. In the assignment of dates and interpolated ages here we follow the magnetic reversal timescale of Gradstein et al. (2004).

$41 \mathrm{Ma}, 33 \mathrm{Ma}, 30 \mathrm{Ma}, 26 \mathrm{Ma}, 20 \mathrm{Ma}, 17 \mathrm{Ma}$, and $10 \mathrm{Ma}$. The time slices are chosen to represent a mixture of some of the better-constrained basin models, and the times of significant tectonic and paleoclimatic epochs in the region. We make no attempt to undo the effects of continental stretching on microcontinent shapes. The reconstructions are illustrated using present-day bathymetry, topography and sub-ice topography. North of $60^{\circ} \mathrm{S}$, we used the ETOPO1 global topography data set (Amante and Eakins, 2009). South of $60^{\circ} \mathrm{S}$ we use the IBCSO and BEDMAP2 data sets (Arndt et al., 2013; Fretwell et al., 2013). The ETOPO1 data set is smoothly blended with its southern neighbours in the region $60-61^{\circ} \mathrm{S}$.

\subsection{Before the Scotia Sea: $50 \mathrm{Ma}$}

Fig. 6 shows the region at a time before small plates had started moving independently within the Scotia Sea. All of the known divergent basins of the Scotia Sea were yet to open, leaving the continental blocks of the southern Scotia Sea and South Scotia Ridge clustered against the northern edge of the South Orkney Microcontinent. We name this region Omond Land, after the Scottish National Antarctic Expedition's Omond House in the South Orkney Islands. Pirie and Bruce banks and Terror Rise occupy the space often taken by South Georgia in reconstructions steered by outcrop tectonostratigraphy. Judged by similar criteria, this placement is not unreasonable because of the similarities between the assemblage of rocks dredged from the banks and the outcrop geology of Tierra del Fuego (Schenke and Udintsev, 2009; Udintsev et al., 2012). The reconstruction uses a distant rotation pole for the opening of Protector Basin, and a mid-distance one for Dove Basin. We rejected a reconstruction using close poles for both basins because it results in a very large overlap between Tierra del Fuego and Patagonia. Conversely, reconstruction with two distant poles results in a large overlap between the Tierra del Fuego shelf and South Scotia Ridge and South Orkney Microcontinent.

From this starting configuration, it is possible to interpret the development of the Scotia Sea as the result of west-northwest-directed extension of a Jurassic-Cretaceous sheared margin that initially formed 


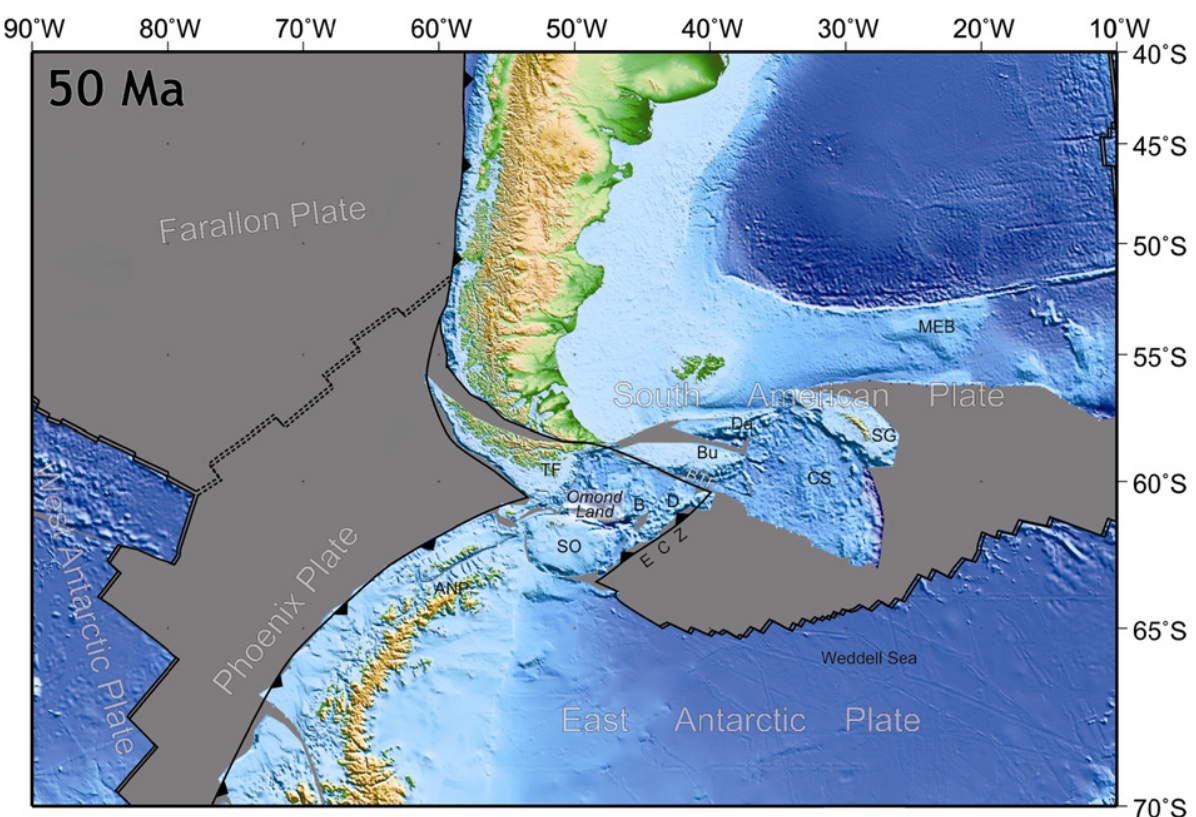

Fig. 6. $50 \mathrm{Ma}$ (chron 22) reconstruction of present-day bathymetry. All motions with respect to present day East Antarctica. See text for a discussion of the uncertainties in this reconstruction. Double lines: mid-ocean ridges (dashed where inferred after Eagles and Scott, in review). Barbed lines: subduction (black barbs). ANP: Antarctic Peninsula, B: Bruce Bank, BTF: Burdwood Transform Fault, Bu: Burdwood Bank, CS: central Scotia Sea, D: Discovery Bank, Da: Davis Bank, ECZ: Endurance Collision Zone, MEB: Maurice Ewing Bank, SG: South Georgia, SO: South Orkney Microcontinent, TF: Tierra del Fuego.

during the early divergence of west and east Gondwana. The sheared margin consists of the eastern edges of Bruce, Discovery, Burdwood and Davis banks. Its neighbouring Mesozoic seafloor is preserved in the central Scotia Sea, but the two are now separated by the younger west Scotia Sea. An extended margin segment that neighboured the sheared segment is preserved on South Georgia. East of South Georgia, a further sheared segment is to be found at the southeast-facing edge of Maurice Ewing Bank (Livermore and Hunter, 1996). The conjugates to these features are to be found along the southern and eastern edges of the Weddell Sea (Eagles, 2010a; Eagles and Vaughan, 2009; König and Jokat, 2006).

The continental crust of Omond Land can be thought of as part of the interior of the East Antarctic Plate, in view of the evidence for South American-Antarctic plate divergence in Tierra del Fuego further north, that came to an end shortly after $50 \mathrm{Ma}$ (Ghiglione et al., 2008). An alternative view would see Omond Land at this time as the site of a broader plate boundary deformation zone in which the inverted extensional basins of Tierra del Fuego were just parts of a northerly branch. The eastern margin of Omond Land was a continent-ocean collision zone, which initiated following a change in South American-Antarctic plate motion from north- to northwest-directed in Maastrichtian to Paleogene times (Barker et al., 1991; Eagles, 2010b). Following Ghidella et al. (2002), we refer to this as the Endurance collision zone. By $50 \mathrm{Ma}$, the collision is likely to have been in progress for long enough $(>10 \mathrm{Myr})$ and to have involved enough shortening $(>100 \mathrm{~km})$ to force subduction of the oceanic lithosphere of the northwest Weddell Sea beneath the South Orkney Microcontinent and Discovery Bank (Leng and Gurnis, 2011). The South American-Antarctic plate boundary reassumes a west-northwest orientation at the northern end of the collision zone, where we invoke a tear fault that continues west-northwest as a transform plate boundary near the northern edges of the restored Bruce and Pirie banks and Terror Rise, and then through northern Tierra del Fuego. The setting and action of this boundary are closely analogous to those of the present-day Scotia-South America plate boundary along the North Scotia Ridge. We refer to it as the Burdwood transform fault where it passes through the embryonic Scotia Sea.

\subsection{Earliest seafloor spreading: $41 \mathrm{Ma}$}

Fig. 7 depicts the Drake Passage region at $41 \mathrm{Ma}$. At this time the central Scotia Sea and South Georgia were still embedded in the South American Plate. The mid-ocean ridge in the northern Weddell Sea had moved about $60 \mathrm{~km}$ further northwest, owing to the slow rate of South American-Antarctic plate divergence that it accommodated. Subduction of South American lithosphere continued beneath the South Orkney Microcontinent at the Endurance collision zone. The Burdwood transform fault connected the collision zone to the wider plate circuit as at $50 \mathrm{Ma}$. The reconstruction features $70 \mathrm{~km}$ of overlap between the northwest corner of the South Orkney Microcontinent and the western end of the South Scotia Ridge. This overlap may be a consequence of deformation of these parts of the ridge as part of the present ScotiaAntarctic plate boundary (Smalley et al., 2007) or by extension during the opening of Powell Basin (Eagles and Livermore, 2002).

The main difference between the situations at $50 \mathrm{Ma}$ and $41 \mathrm{Ma}$ is that plate divergence processes had started to dissect Omond Land. Alkali basalts dredged from Powell Basin suggest thinning of the lithosphere between the South Orkney Microcontinent and Antarctic Peninsula (Barber et al., 1991). Crustal extension is also expressed in a set of grabens crossing the shelf south of the microcontinent (King and Barker, 1988). Palynological analysis of core samples indicates rapid subsidence of Bruce Bank in the run-up to this time (Mao and Mohr, 1995), which can be related to continental extension between it and Pirie Bank. By $41 \mathrm{Ma}$, this extension had likely given way to spreading in an oceanized Dove Basin (Barker et al., 2013; Eagles et al., 2006). These motions, decoupled from the interior of the South American Plate by motion on the Burdwood transform fault, define an independentlymoving plate whose southeastern edge is likely to have been occupied by a volcanic arc ancestral to Discovery and Jane banks. The younger reconstructions show that this plate's boundaries evolve in such a way that it grows to incorporate the central Scotia Sea, so that it is appropriate to name it the Central Scotia Plate here. Extension in Powell and Dove basins may have started as a response to southeast-directed trench motion at this plate's southeastern edge, and/or to changes in 
40

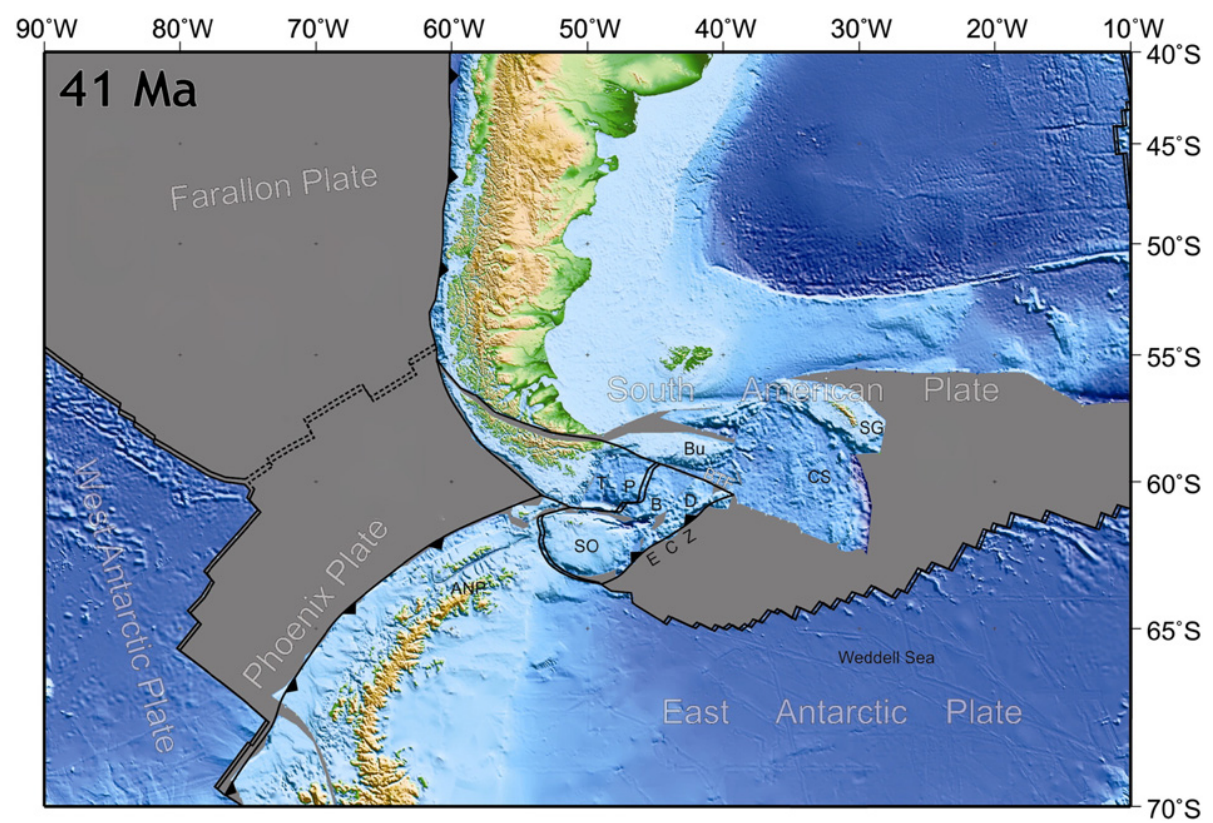

Fig. 7. $41 \mathrm{Ma}$ (chron 13) reconstruction of present-day bathymetry. See text for a discussion of the uncertainties in this reconstruction. All motions with respect to present day East Antarctica. Symbols and abbreviations are the same as in Fig. 6 plus P: Pirie Bank, T: Terror Rise.

the shear stress state along the Burdwood transform fault as the azimuth of South American-Antarctic plate motion rotated at 50-41 Ma (Eagles et al., in preparation; Livermore et al., 2005).

The shape of the narrow gap between Tierra del Fuego and South America changes only slightly between the $50 \mathrm{Ma}$ and $41 \mathrm{Ma}$ reconstructions. The changes are small, and taken at face value might be interpreted in terms of $<50 \mathrm{~km}$ of left-lateral transpression. This process would not be inconsistent with the widespread evidence for crustal shortening in Tierra del Fuego during the same period (e.g. Gombosi et al., 2009; Kraemer, 2003), but the change it is interpreted from is well within the range of uncertainties that might be tolerated from different choices of Powell and Dove basin rotations.

\subsection{The Central Scotia Plate grows: $33 \mathrm{Ma}$}

The reconstruction for $33 \mathrm{Ma}$ is shown in Fig. 8. The consequences of motion between west and east Antarctic plates are depicted by reconstruction of modest oblique stretching east of Alexander Island in the George VI Trough (Cande et al., 2000; Eagles et al., 2009b). The South American-Antarctic Ridge in the Weddell Sea has moved further to the northwest. At its western end it gives way to the Endurance collision zone. As in the earlier reconstructions, the trench and arc of the collision zone are shown present as far north as the northern end of Discovery Bank, where they meet the Burdwood transform fault. By $33 \mathrm{Ma}$, this fault had lengthened as a result of Dove Basin widening, and reached

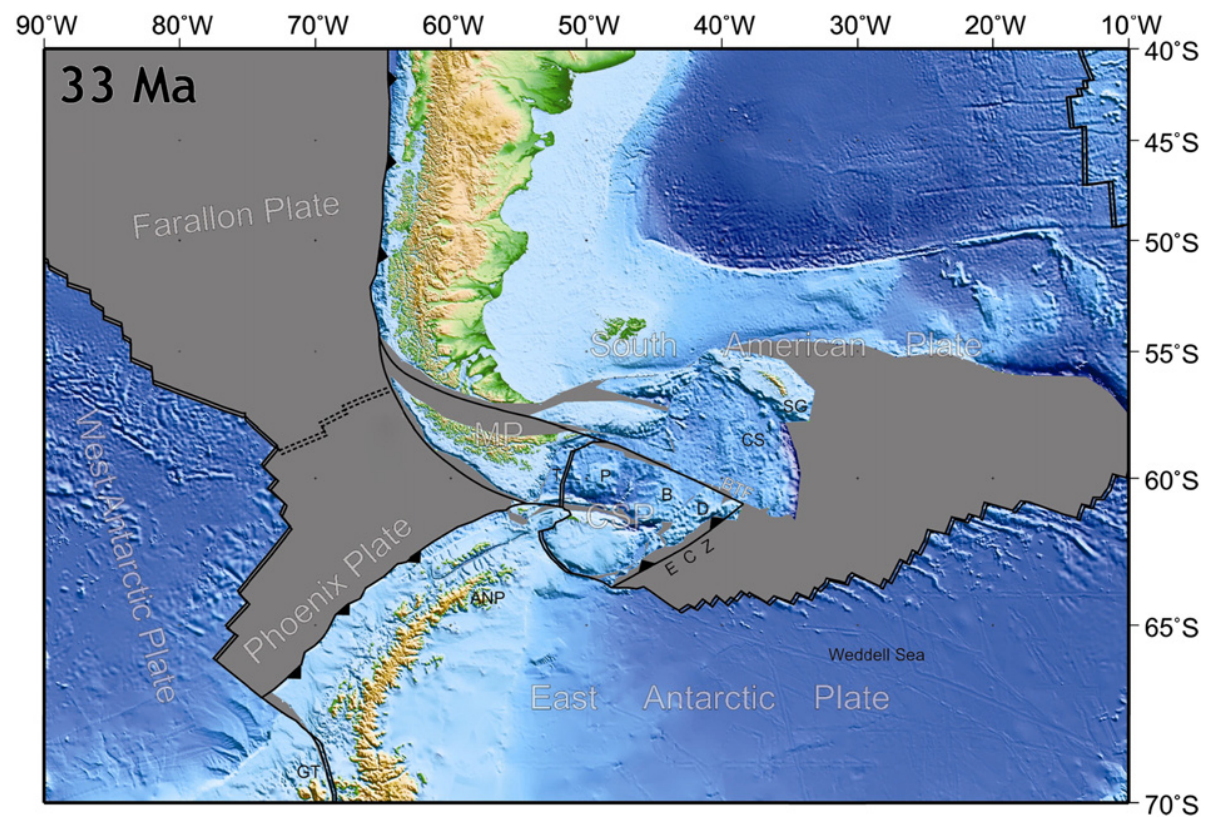

Fig. 8. $33 \mathrm{Ma}$ (chron 13) reconstruction of present-day bathymetry. See text for a discussion of the uncertainties in this reconstruction. All motions with respect to present day East Antarctica. Symbols are the same as in Figs. 6 and 7 plus CSP: Central Scotia Plate, MP: Magallanes Plate. 
half the length of its present-day counterpart on the North Scotia Ridge. The central Scotia Sea and South Georgia remain in the interior of the South American Plate to the north of this boundary. South of it, the site of divergence between the Central Scotia Plate and Tierra del Fuego has jumped to the Protector Basin, abandoning Dove Basin in the interior of the Central Scotia Plate and incising Omond Land further. Powell Basin continues to open by continental stretching.

The underlap through Tierra del Fuego widens by around $100 \mathrm{~km}$ between the $41 \mathrm{Ma}$ and $33 \mathrm{Ma}$ reconstructions. Overall, northward widening of the Scotia Sea region is a robust requirement of the northwest-directed South American-Antarctic motion in this period, and there is indeed evidence for contemporary extension in Tierra del Fuego, at the Sloggett Basin (Ghiglione et al., 2008). The crustal thinning associated with the basin's growth is not quantified. As our circuit construction concentrates its largest summed uncertainties on this boundary, we consider in any case that the $100 \mathrm{~km}$ figure for the boundary's widening would be unsuitable as a basis for calculating or comparing any estimate of crustal thinning. Being subject only to uncertainty in the Powell Basin reconstruction parameters, motion along the modelled Burdwood transform fault can be interpreted with some more confidence as dominantly strike-slip between 41 and 33 Ma.

6.4. Capture of the central Scotia Sea and the nascent West Scotia Ridge: $30 \mathrm{Ma}$

Large changes happened in the tectonics of the Scotia Sea by $30 \mathrm{Ma}$, as depicted in Fig. 9. The figure shows how Protector Basin, like Dove Basin before it, was abandoned in favour of a more westerly locus of spreading. The new site lies between Terror Rise and eastern Tierra del Fuego, and goes on to become the southern part of the west Scotia Sea. The full-fit rotation for the west Scotia Sea was derived from reconstruction of the tabular magnetic anomalies on Terror Rise and in Tierra del Fuego (Fig. 5). The 30 Ma date for the reconstruction is determined by linear extrapolation of post-chron 8 seafloor spreading rates or angular rates in the west Scotia Sea to meet this full-fit rotation. This date coincides with the independently-determined end of spreading in Protector Basin at chron 11n.2 (30.2-29.7 Ma; Eagles et al., 2006). Based on our model, therefore, 11n.2 would be the oldest magnetic isochron to be expected at the margins of the west Scotia Sea south of Tierra del Fuego and west of Terror Rise. Further south, completing the dismemberment of Omond Land, Powell Basin is undergoing oceanisation after the lengthy continental stretching between the Central Scotia Plate (the arc plate) and Antarctic Peninsula.

The South American-Antarctic ridge in the Weddell Sea changed only slightly from its condition at $33 \mathrm{Ma}$ because of the slow spreading rates it operated at. Calc-alkaline volcanism dated to 29-33 Ma and well north of Discovery Bank in the present fore-arc shows that the Endurance collision zone had lengthened northwards (Barker, 1995; Livermore et al., 1994). We show it having reached South Georgia. This lengthening needed to have occurred by rupturing old lithosphere of the South American Plate to the east of what was to become the central Scotia Sea. Eagles (2010b) speculated that rupture may have been eased by the availability of a north-trending crustal asperity in the form of a Mesozoic fracture zone. The impetus for the trench to lengthen is more difficult to understand. Perhaps it was related to loading of the South American Plate from below, as its subducted parts moved northwards beneath the central Scotia Sea, setting up a downward mantle flow near its eastern edge.

Whatever their causes, the consequences of these events are important for the Scotia Sea. Trench lengthening saw the older Burdwood transform fault abandoned in favour of a new fault at the new, more northerly, tip of the subduction zone. This fault remains active to the present day along the North Scotia Ridge. At 30 Ma its exact path through or around South Georgia is unknown, but can be expected from its gross orientation to have acted overall in plate convergence in the east and as a tear fault further west. Further west, the tear fault connected to the existing plate boundary in Tierra del Fuego via the Falkland Trough, which our rotations suggest accommodated very little motion in the 33-30 Ma period. With this, the central Scotia Sea became encircled by new plate boundaries that excised it from the South American Plate. The central Scotia Sea started to move as part of the Central Scotia Plate to which it gives its name.

\subsection{Organised seafloor spreading in the west Scotia Sea: $26 \mathrm{Ma}$}

By 26 Ma (Fig. 10), seafloor spreading was well established on the West Scotia Ridge and the ridge in Powell Basin (Eagles and Livermore, 2002; Eagles et al., 2005). Spreading was at slow rates on both ridges so it can be expected that each would have hosted a median valley (Small, 1998). In the west Scotia Sea, anomaly 8 (26.2 Ma) is

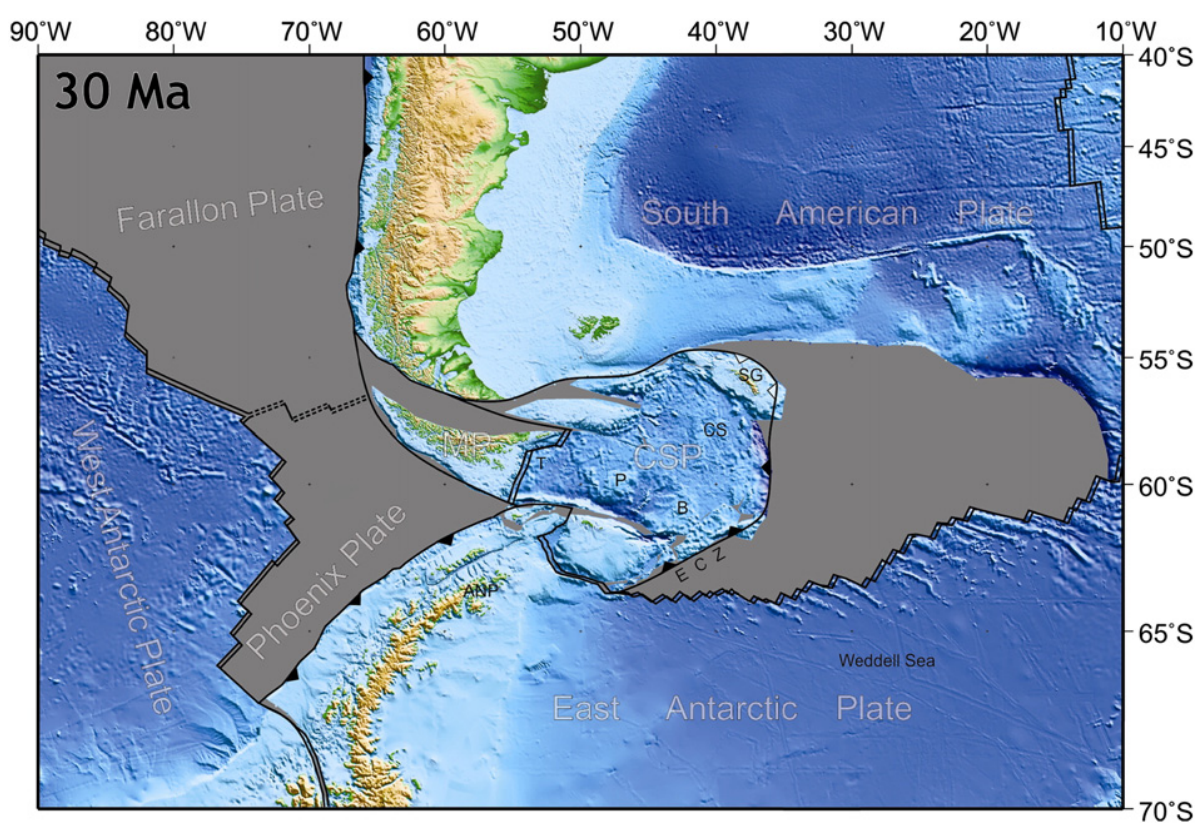

Fig. 9. $30 \mathrm{Ma}$ (chron 11) reconstruction of present-day bathymetry. See text for a discussion of the uncertainties in this reconstruction. All motions with respect to present day East Antarctica. Symbols are the same as in Fig. 6, plus lines with white barbs: collision zones. Abbreviations are the same as in Figs. 6-8. 
42

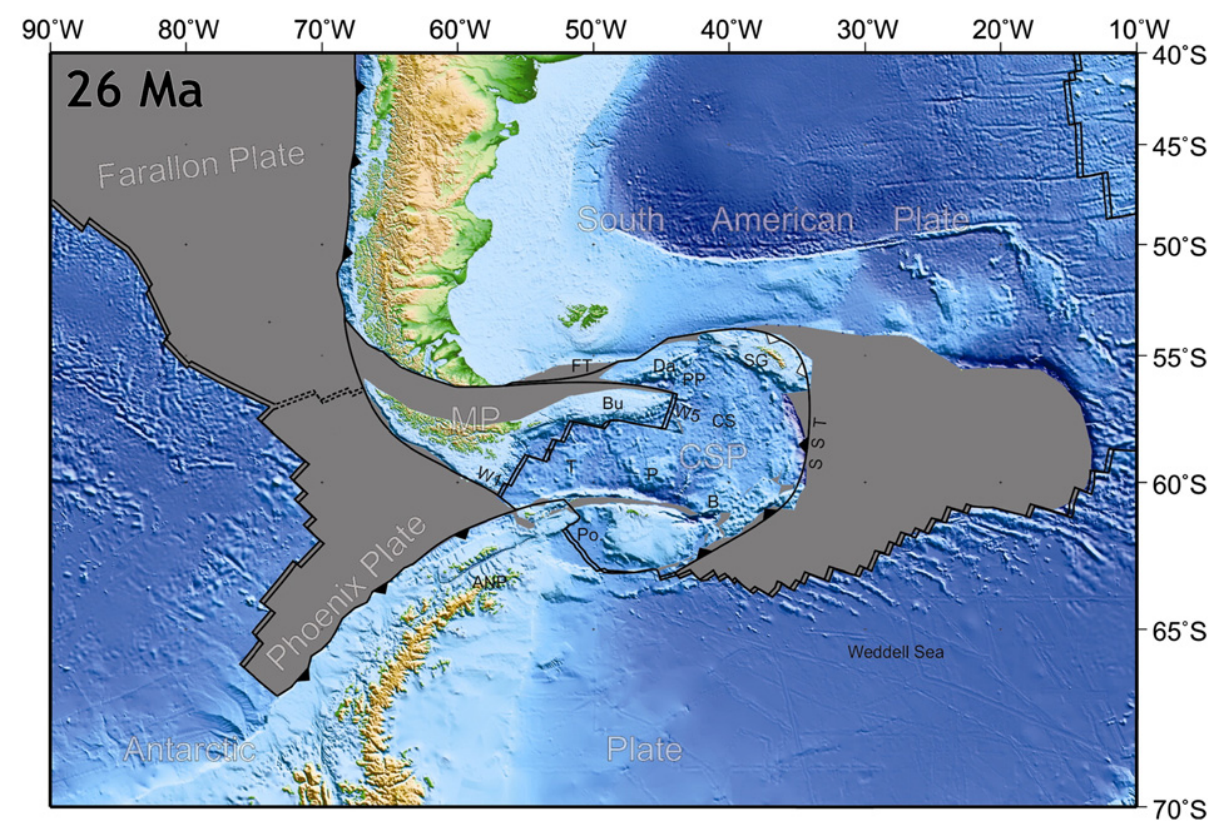

Fig. 10. $26 \mathrm{Ma}$ (chron 8) reconstruction of present-day bathymetry. See text for a discussion of the uncertainties in this reconstruction. All motions with respect to present day East Antarctica. Symbols and abbreviations are the same as in Figs. 6-9 plus FT: Falkland Trough, Po.: Powell Basin, PP: Pirie Province, SST: South Sandwich Trench, W1, W5: numbered segments of the West Scotia Ridge.

interpreted on both flanks of the ridge in corridors W1-W5 (Fig. 3; Eagles et al., 2005). North of this, we envisage the eastwards motion of the Central Scotia Plate as being accommodated by oblique continental extension in the Davis Bank-western Falkland Trough area. The underlap north of Tierra del Fuego in this reconstruction has increased slightly to $160 \mathrm{~km}$ from its size at 33-30 Ma. Such an increase is indistinguishable from the errors expected in the combination of rotations for reconstructions of the South American-Antarctic, West Scotia and Powell basins.

Volcanism might be expected to have continued to this time at the Pirie Province, although its dredged volcaniclastic rocks only yield dates of $29 \mathrm{Ma}$ and $11 \mathrm{Ma}$ (Dalziel et al., 2013b; Pearce et al., submitted for publication). Similar rocks have been dredged, but not dated, from the neighbouring Davis Bank (Pandey et al., 2010). At $26 \mathrm{Ma}$, this part of the Scotia Sea may have been dotted with volcanic islands on a shallow platform. If this volcanism was subductionrelated as Dalziel et al. (2013b) suggest, then the South American slab beneath this part of the Scotia Sea must have been subducting at a low angle in the range $10-20^{\circ}$, in view of its $>500 \mathrm{~km}$ separation from the trench southeast of South Georgia. Alternatively, the volcanism may represent partial remelting of immature lower crust by the addition of mantle melts formed during the region's extension, in a manner similar to that suggested for the much older Chon Aike large igneous province (Pankhurst and Rapela, 1995).

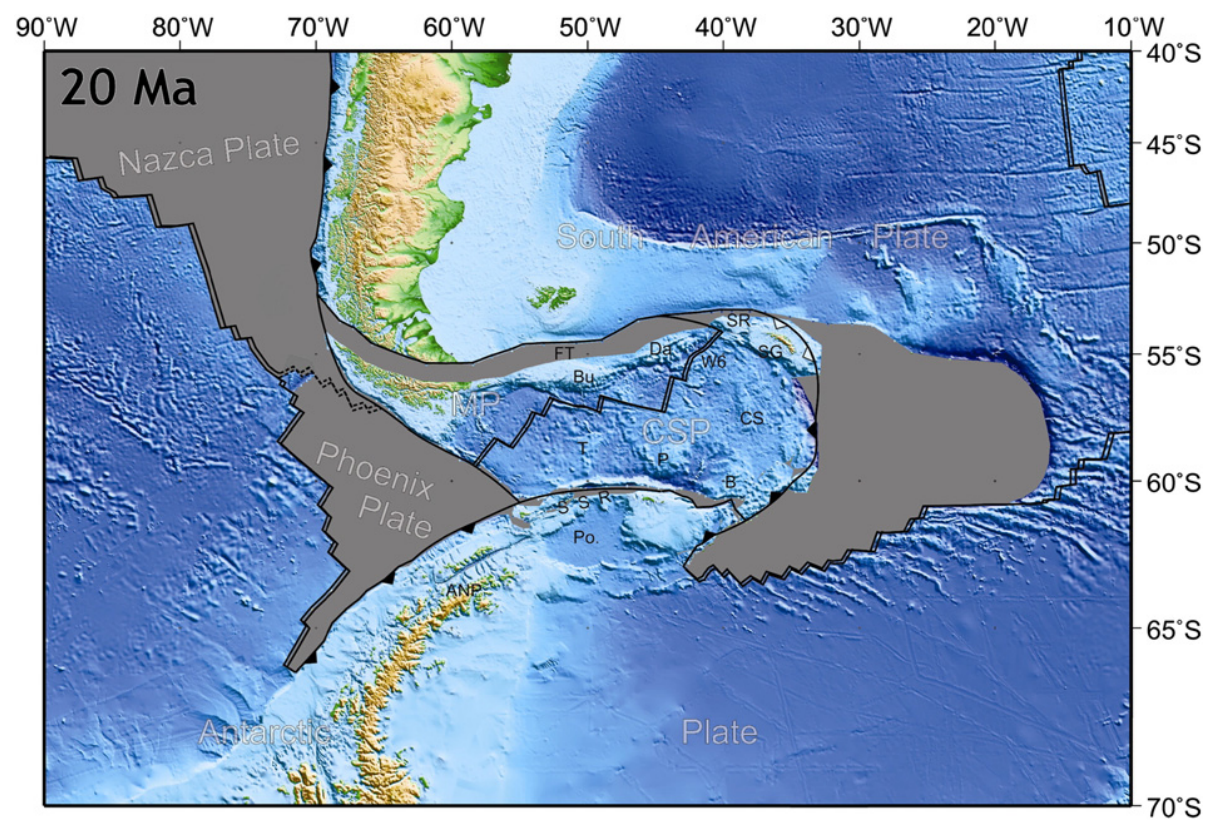

Fig. 11. $20 \mathrm{Ma}$ (chron 6) reconstruction of present-day bathymetry. See text for a discussion of the uncertainties in this reconstruction. All motions with respect to present day East Antarctica. Symbols and abbreviations are the same as in Figs. 6-10 plus SR: Shag Rocks Bank, SSR: South Scotia Ridge, W6: numbered segment of the West Scotia Ridge. 


\subsection{Spreading ends in Powell Basin: $20 \mathrm{Ma}$}

Fig. 11 illustrates the next major change in the tectonics of the Scotia Sea. Seafloor spreading ceased in Powell Basin shortly before the time of this reconstruction, perhaps at chron 6AA ( 21 Ma; Eagles and Livermore, 2002). This event coincided with the arrival of segments of the South American-Antarctic Ridge at the Endurance collision zone (Barker, 1995; Barker et al., 1982, 1984; Hamilton, 1989). In view of these collisions, the coincidence between these events can be interpreted in terms of changes in the driving forces controlling the motion of the trench, and with it the central Scotia (arc) plate. With the southern part of the trench and the ridge in Powell Basin now inactive, the central Scotia-Antarctic plate boundary reorganised and relocated. In Fig. 11 we portray its new site on the South Scotia Ridge. At $20 \mathrm{Ma}$, there are few direct constraints on plate motion at this boundary, for which the rotation is an extrapolation of the betterconstrained central Scotia-Antarctica rotation at $17 \mathrm{Ma}$. According to this extrapolation, strain along the plate boundary may have happened by slow sinistral transpression.

By 20 Ma the West Scotia Ridge had propagated north into the region between Davis Bank and the Pirie Province, presumably generating a median valley between them (Fig. 3). At its northern end, just south of Shag Rocks, motion on the ridge was transformed westwards into the Falkland Trough. Shag Rocks bank thus remained juxtaposed with South Georgia and, initially, with northern Davis Bank across the transform fault. This time may also have seen subduction of parts of a Phoenix-Nazca ridge crest south of Cape Horn, opening a slab window that has been related to the occurrence of alkali basalt volcanism at Packsaddle Island (Breitsprecher and Thorkelsen, 2009; Eagles et al., 2009a; Puig et al., 1984). By removing an along-ridge larval dispersal route between the Pacific Ocean and Scotia Sea, such a collision may also have contributed to the 25.9-13.4 Ma divergence in Kiwaid crab biogeography, which is otherwise attributed to the onset of the Antarctic Circumpolar Current (Roterman et al., 2013).

The reconstruction shows the width of the underlap across the western Falkland Trough and through northern Tierra del Fuego to reduce, from $\sim 155 \mathrm{~km}$ at 30-26 Ma, to $80 \mathrm{~km}$. Although the magnitude of this change is likely to be smaller than the errors resulting from simple combination of the South America-Antarctica and Magallanes-Central Scotia rotations, its sense is clearly required by any reconstruction that seeks to combine those rotations without producing a seeminglyunreasonable reconstruction overlap on the South Scotia Ridge. Plate convergence in Tierra del Fuego and the western Falkland Trough at 26-20 Ma is therefore a reasonable requirement of our circuit-closure considerations, and is evident in the form of an accretionary prism at Burdwood and Davis banks, and young structures in the fold and thrust belt of Tierra del Fuego (Bry et al., 2004; Cunningham et al., 1998; Klepeis and Austin, 1997; Kraemer, 2003).

\subsection{Rupture of the Central Scotia Plate: $17 \mathrm{Ma}$}

The major plate situation depicted for $17 \mathrm{Ma}$ in Fig. 12 is similar to that in Fig. 11. In addition, part of the former Phoenix Plate in the major plate circuit is juxtaposed with the southern continental margin of Tierra del Fuego on the Magallanes Plate, in the smaller Scotia Sea plate circuit. Placing the interior of the Scotia Sea within the reconstruction according to a simple 17 Myr-long extrapolation of Smalley et al.'s Scotia-Antarctica rotation parameters results in an overlap of these elements, which implies plate divergence between the two that is unlikely considering the Fuegian margin's accretionary nature (Polonia et al., 1999). Simply adopting different angles about Smalley et al.'s (2007) pole sets up a difficult-to-justify trade off between this overlap and another one between the central Scotia and Antarctic plates on the South Scotia Ridge. Instead, we link the reconstruction elements with an ad hoc central Scotia-Antarctica rotation that is designed to avoid overlap and underlap between Tierra del Fuego and the Phoenix Plate, and reproduce the slow and slightly transpressional strain on the South Scotia Ridge that interpretations of seismic profiles suggest it may have accommodated (Galindo-Zaldivar et al., 1996; Kavoun and Vinnikovskaya, 1994; Lodolo et al., 2010).

Fig. 12 shows two large changes within the Scotia Arc. The first change is further northward propagation of the West Scotia Ridge through the North Scotia Ridge and into the Falkland Trough, by which Shag Rocks and Davis banks finally separated. The interpolated rotation we use to juxtapose Shag Rocks with South Georgia suggests that this propagation occurred at $18.5 \mathrm{Ma}$. The resulting breach in the North Scotia Ridge is occupied today by Barker Bank, beneath which magnetic reversal anomalies suggest that oceanic basement may lie. Barker Bank may in large part therefore consist of a build up of sediments deposited where fast bottom currents turn on their way into

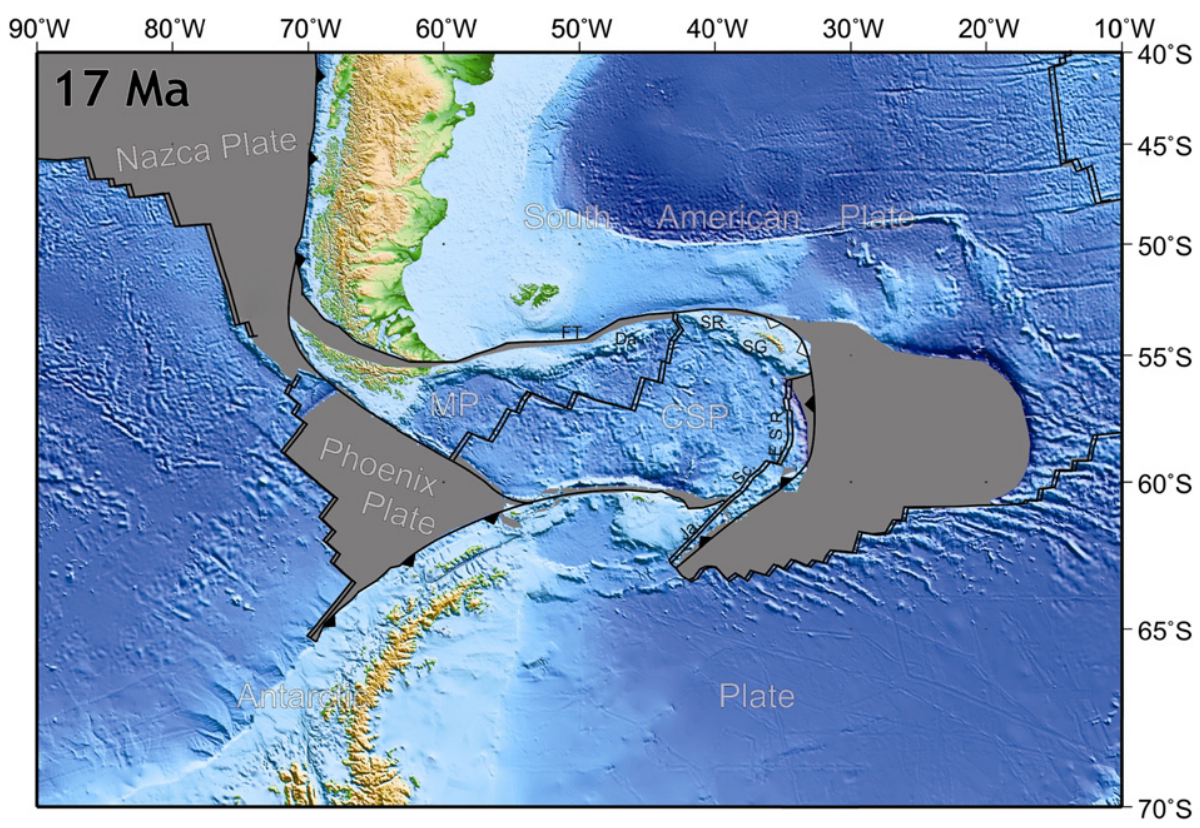

Fig. 12.17 Ma (chron 5C) reconstruction of present-day bathymetry data with plate outlines. See text for a discussion of the uncertainties in this reconstruction. All motions with respect to present day East Antarctica. Symbols and abbreviations are the same as in Figs. 6-11 plus ESR: East Scotia Ridge, Ja.: Jane Basin, Sc.: Scan Basin. 
the Falkland Trough. The second change is the onset of plate divergence in the East Scotia Sea (Vanneste and Larter, 2002). In keeping with our assumption of a rigid single arc plate, we show this early basin as a continuous feature with Scan and Jane basins. Rupture of the Central Scotia Plate in these locations allowed the proto-Sandwich plate to rift off it Motion of this new arc plate immediately started to accommodate eastwards migration of the South Sandwich Trench so that plate divergence in the west Scotia Sea slowed considerably. The underlap region at the North Scotia Ridge and in Tierra del Fuego closed to less than $30 \mathrm{~km}$ in the 20-17 Ma period, indicating continued plate convergence in those locations.

\subsection{The senescent West Scotia Ridge: $10 \mathrm{Ma}$}

In Fig. 13, as in the $17 \mathrm{Ma}$ reconstruction, the plate circuit at $10 \mathrm{Ma}$ is completed using a rotation that is designed to avoid overlap between the Phoenix and Magallanes plates. The rotation is slight, and the strain it insinuates on the South Scotia Ridge is very similar to that by the present-day GPS-derived rotation of Smalley et al. (2007). We interpret this as an indication of the onset of modern-like motion following ridgecrest-trench collisions in the northwest Weddell Sea and deactivation of Scan and Jane basins as sites of plate divergence. The North Scotia Ridge, in contrast, continued to act as two separate plate boundaries, in the west between the Magallanes and South American plates, and in the east between the central Scotia and South American plates. Its slight $(15 \mathrm{~km})$ reconstruction underlap and right-handed offset illustrate that the last 10 million years have seen slow sinistral transpression accommodated along most of its length. The spreading rate on the West Scotia Ridge had continued to decrease slightly since its marked reduction at $17 \mathrm{Ma}$, although it never reached ultra-slow spreading rates (Eagles et al., 2005). In the interior of the Central Scotia Plate, renewed volcanism around this time has been related to subduction at the South Sandwich Trench of an aseismic ridge of the Northeast Georgia Rise large igneous province (Dalziel et al., 2013b; Pearce et al., submitted for publication).

\subsection{Birth of the Scotia Plate: $6 \mathrm{Ma}$}

Fig. 14 depicts the beginning of the modern plate tectonic era in the Scotia Sea, which began with the end of plate motions on the West
Scotia Ridge between $6 \mathrm{Ma}$ and $5 \mathrm{Ma}$ (Eagles et al., 2005). The Magallanes and Central Scotia Plates amalgamated to form the Scotia Plate. Consequently, since $6 \mathrm{Ma}$ the North and South Scotia ridges have constituted the northern and southern boundaries of the Scotia Plate with the South American and Antarctic plates. We use Smalley et al.'s (2007) GPS-derived Euler rotation for Scotia-Antarctic motion to close the reconstruction. In order to crudely depict small motions within the South Scotia Ridge, which have given rise to its dissection and the development of deep transtensional basins at releasing bends (Galindo-Zaldívar et al., 1996), we apply Smalley et al.'s (2007) rotation with just half of the angle to the northern blocks of the ridge. At the eastern end of the Scotia Plate, the Sandwich Plate has grown as a result of back-arc spreading in the period since $17 \mathrm{Ma}$. Further west, the last corner of the Phoenix Plate is still actively subducting beneath the Antarctic Peninsula. Its northeast-facing edge at this time is a strongly oblique-convergent plate boundary with the Scotia Plate. The oblique convergence, by $6 \mathrm{Ma}$, had resulted in flexural uplift of the plate edge, producing a linear ridge at the Shackleton Fracture Zone which persists to the present day (Livermore et al., 2004).

\section{Discussion: Paleobathymetric development of Drake Passage}

In Figs. 6-14, we made no attempt to reconstruct the topographic effects of any processes other than plate motion. Despite this, large scale geodynamic and surface processes such as thermal contraction of the cooling oceanic lithosphere, tectonic thinning and flexure of the lithosphere at plate boundaries, or loading and unloading by erosion and sedimentation can be taken into consideration using simple kinematic models (e.g. Wilson et al., 2012). Doing so in the Scotia Sea however requires regional data sets that do not yet exist at adequate resolution, coverage, or reliability. Models and knowledge of the sensitivity of biogeographic and paleoclimate processes to paleobathymetry in Drake Passage, however, are not yet so fine that they would justify the precision anticipated from this kind of work. Instead, paleoclimate studies with general and ocean circulation models have tended to focus on the question of when Drake Passage may have opened as a through-going connection between the Pacific and Atlantic basins in deep $(>2.5 \mathrm{~km})$, intermediate $(1.0-2.5 \mathrm{~km})$, or shallow $(<1 \mathrm{~km})$ water. Biogeographical studies are more concerned with environmental

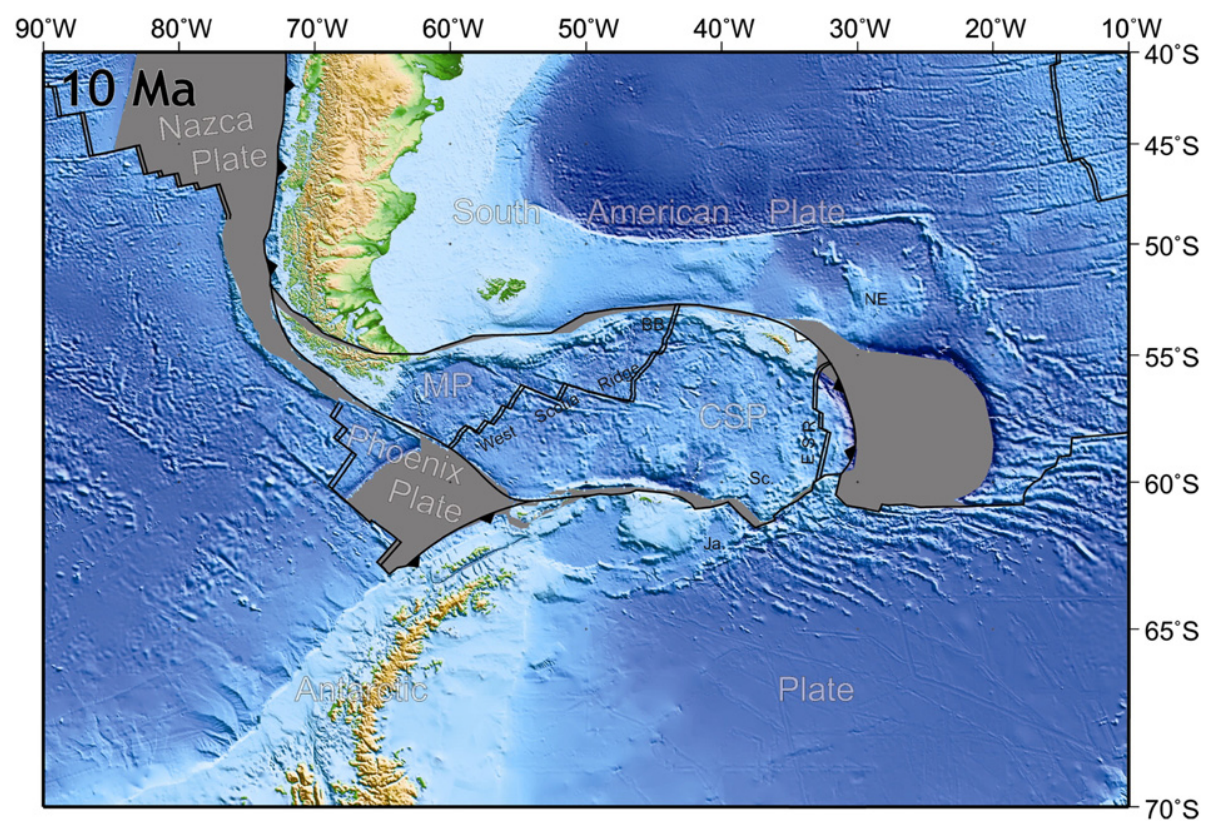

Fig. 13. $10 \mathrm{Ma}$ (chron 5) reconstruction of present-day bathymetry. See text for a discussion of the uncertainties in this reconstruction. All motions with respect to present day East Antarctica. Symbols and abbreviations are the same as in Figs. 6-12 plus BB: Barker Bank, NE: Northeast Georgia Rise. 


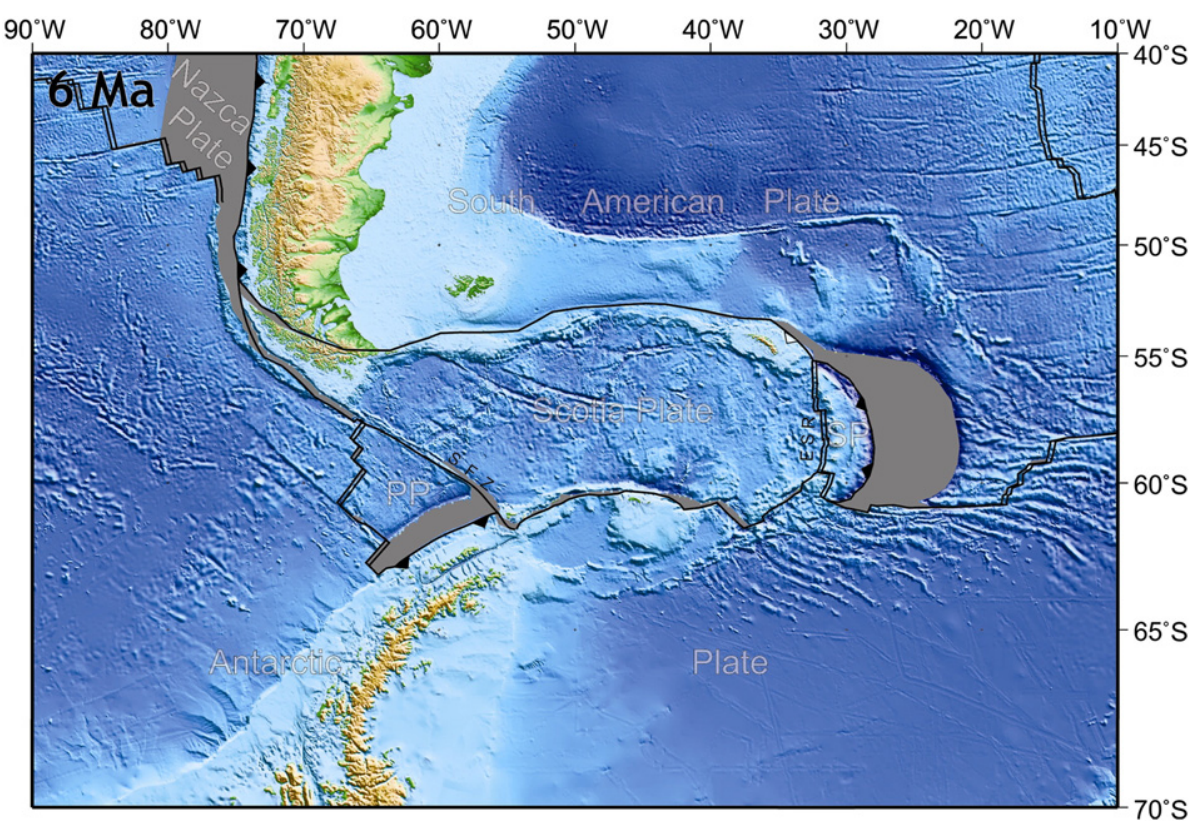

Fig. 14. $6 \mathrm{Ma}$ (chron 3A) reconstruction of present-day bathymetry. See text for a discussion of the uncertainties in this reconstruction. All motions with respect to present day East Antarctica. Symbols and abbreviations are the same as in Figs. 6-13 plus SFZ: Shackleton Fracture Zone.

classifications of paleotopography, and most crudely the distinction between terrestrial and marine environments.

Fig. 15 abstracts the information of Figs. 6-14 in terms of these depth classes. To make it, we note that the largest scale of processes at which we expect areas of seafloor to have moved rapidly between depth classes is the plate boundary scale. With these considerations in mind, we made manual adjustments in a computer drawing package to the reconstructed present-day bathymetry of Figs. 6-14. We worked backwards in time through the reconstructions, applying the adjustments according to the following scheme:

a) The short durations of steps between time slices are such that thermal subsidence is not likely to have caused intraplate regions to cross between depth classes. Such regions thus remain in the same depth class they had for the younger time slice;

b) Plate boundary areas on continental basement that would be expected to have responded to plate convergence with crustal thickening between two time slices move down one depth class in the time slice preceding the convergence. These areas often appear as underlaps in Figs. 6-14;

c) Plate boundary areas on continental or oceanic basement that would be expected to have responded to plate convergence-related loading by regional flexure move up one depth class in the time slice preceding the convergence. These areas also often appear as underlaps in Figs. 6-14;

d) Plate boundary areas on continental basement that would be expected to have responded to plate divergence by extensional basin formation move up one depth class in the time slice preceding the divergence;

e) Areas move up a depth class if they were experiencing arc or intraplate volcanism in the older of two time slices but not in the younger;

f) We account for the loss of the northern precursor of the South Sandwich arc to subduction erosion by simply assuming that it resembled its present successor; and

g) Areas shown as underlaps resulting from subduction at the South Shetland and South Sandwich trenches and Endurance collision zone are depicted in the deep class, under the assumption they must have consisted of oceanic lithosphere.
These considerations are undoubtedly crude but they fulfil many basic expectations of the bathymetric change behaviour for plate interiors and plate boundary zones. Their uncertainties are large and, we consider, most critical for the difference between terrestrial and intermediate classes. To depict the effects of this particular uncertainty, we include a fourth depth class, which we label 'coastal', at $\pm 150 \mathrm{~m}$ of present-day sea level. Processes that have not been taken explicitly into consideration include erosion and sedimentation, dynamic topography, and glacial and other eustatic sea level variations.

At $50 \mathrm{Ma}$, Fig. 15 depicts extensional basins in easternmost Tierra del Fuego to host localized seas in the coastal and shallow depth classes. To the west and south, the reconstruction shows Omond Land as an $\sim 250 \mathrm{~km}$ wide archipelago or coastal plain connecting Tierra del Fuego and the northern Antarctic Peninsula. As noted above, we have not accounted for the areal effects of any continental stretching in our reconstructions. With typical integrated stretching factors for continental margin settings, the real width of Omond Land may have been closer to $120 \mathrm{~km}$. On millennial timescales, we consider the 50 Ma time slice to show, in effect, a complete terrestrial connection between South America and Antarctica. With the onset of extension in Powell and Dove basins after $50 \mathrm{Ma}$, however, subsidence related to crustal thinning of the northern peninsula, South Orkney Microcontinent and Pirie and Bruce banks produces a continuous gateway in the shallow depth class. By $41 \mathrm{Ma}$, shallow ( $<1 \mathrm{~km}$ ) ocean floor dominates eastern and southern Omond Land, cross-cut by troughs of intermediate and deep floor related to the onset of rifting and spreading in Powell and Dove basin and their connections to the Pacific margin. Scher and Martin (2006) described Nd isotopic evidence in core samples from the Pacific and Atlantic oceans for the establishment of this connection. Along with Eagles et al. (2006), they speculated on the role that such a connection may have played in long-term global changes leading up to the perennial glaciation of Antarctica.

By $30 \mathrm{Ma}$, volcaniclastic rocks in dredge samples from the Pirie Province suggest that subaerial volcanic peaks may have existed in the northern Scotia Sea (Dalziel et al., 2013b; Pearce et al., submitted for publication). An unsampled north-south trending swell further east in the central Scotia Sea may have a similar origin, and so may also have sported such features at this time. Polarstern Basin to the south, however, is smooth-floored and deep and preserves no sign of 


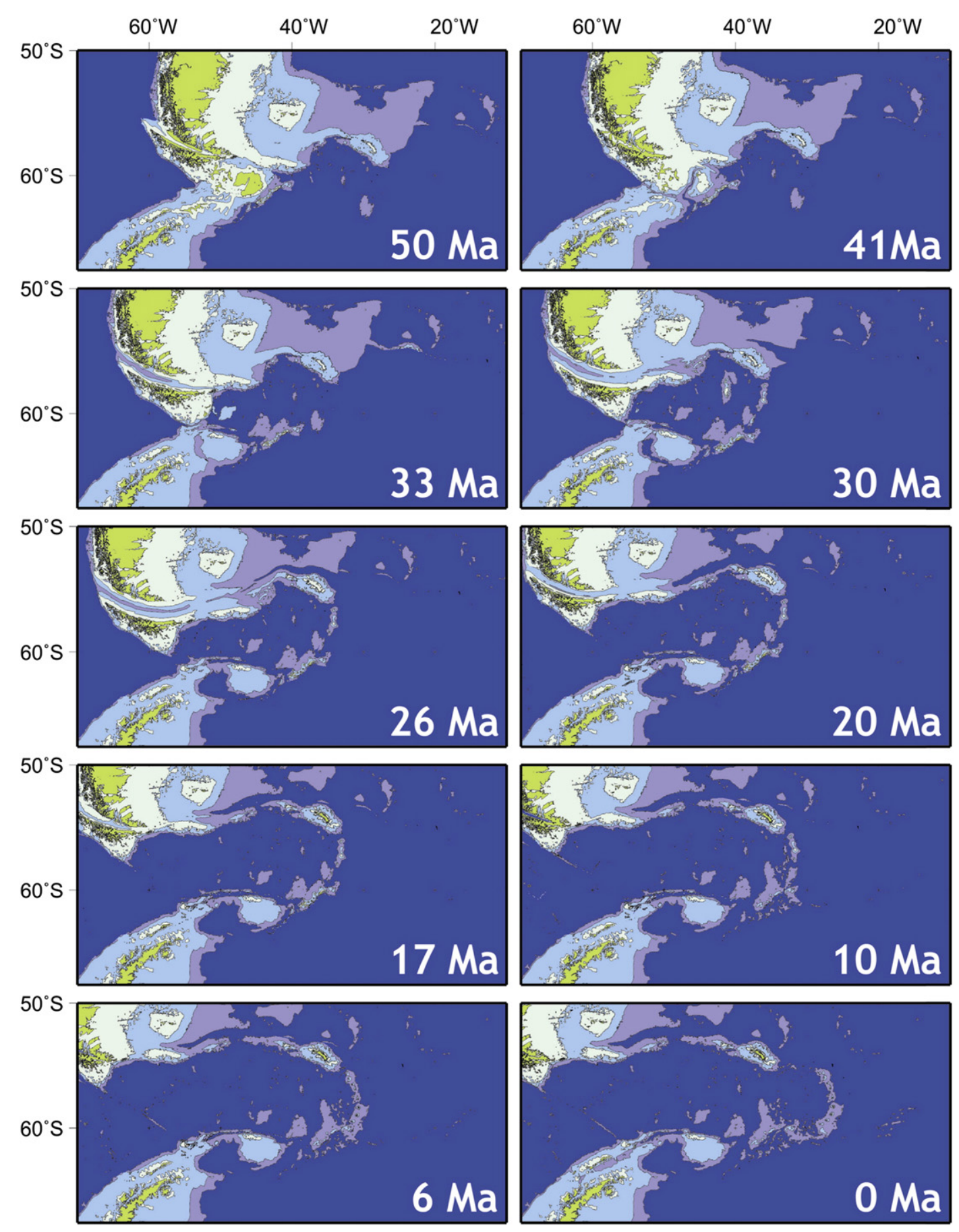

Fig. 15. Simple paleobathymetric reconstructions of Drake Passage based on present-day bathymetry and the tectonic reconstructions in Figs. $6-14$. Dark blue: deep ( $>2.5$ km), mid blue: intermediate (2.5-1.0 km), light blue: shallow ( $<1.0 \mathrm{~km})$, light green: 'coastal' ( $\pm 150 \mathrm{~m})$, green: terrestrial.

processes that might have led to its subsidence from much shallower depths at $30 \mathrm{Ma}$; it is likely to have been present at similar depths to today's. Further south still, Terror Rise and Pirie Bank will have experienced two periods of extension each, as precursors to the separate phases of seafloor spreading each side of them. They can be expected to have undergone extreme lithospheric and crustal thinning, and thus since at least $30 \mathrm{Ma}$ to have been present at intermediate depths similar to today's, where they interrupt the continuity of deeper seafloor in the neighbouring Protector and Dove basins. At the eastern edge of the Scotia Sea, an arc of subduction-related volcanic islands like the present-day South Sandwich islands is shown adorning the intermediate-to-shallow pedestals of Discovery Bank and the now-subducted paleo-arc northwards of it towards South Georgia
(Vanneste and Larter, 2002). Consequently, although intermediatedepth parts of the continental slopes off the northern Antarctic Peninsula and southern Tierra del Fuego part to form a narrow deep proximal gateway at $30 \mathrm{Ma}$, eastward flow of deep water through the Scotia Sea is likely to have been possible only via tortuous pathways, leading to turbulence and strong vertical mixing, and thus considerable complexity in any proto-polar front.

In the 26-20 Ma period, a broad (100-300 km) unbroken gateway into the Scotia Sea opened over deep $(>2.5 \mathrm{~km})$ seafloor between Terror Rise and Tierra del Fuego. Continuous deep new oceanic crust formed west and north of Terror Rise. At the start of this period, the West Scotia Ridge would have existed with a median valley between this connection and the eastern edge of Burdwood Bank, and by the 
end would have been present as far north as Davis Bank and the Pirie Province, leading to their faulting and subsidence. Hence, a continuous and moderately wide deep water path would have existed as far east as Bruce Bank and as far north as Shag Rocks. With the North Scotia Ridge still unbroken at intermediate levels, the possibility and nature of deep transport out of the Scotia Sea would still have depended on the presence and shape of precursors to the South Sandwich Arc north of Discovery Bank.

17 Ma sees the West Scotia Ridge having propagated further north to breach the North Scotia Ridge at Barker Bank, forming the oceanographic Shag Rocks passage. Above we noted that this propagation may date from $18.5 \mathrm{Ma}$. The passage reached its full width of around $80 \mathrm{~km}$ by $6 \mathrm{Ma}$, when spreading ended in the west Scotia Sea. Deep frontal water that was channelled north along the West Scotia Ridge would therefore have had the opportunity to enter the Falkland Trough since 18.5-17 Ma. At the present day, a portion of this water circulates west into the trough, where it has given rise to the development of the South Falkland Slope Drift. Koenitz et al. (2008) suggested the drift dates from 20.6 Ma on the basis of extrapolated sedimentation rates and a supposed Miocene age for the basement of the central Scotia Sea (Maldonado et al., 2003). Our reconstructions do not support the existence of such a basement age constraint, so that it seems more reasonable to suggest the seismic stratigraphy of the drift should begin with the opening of the Falkland Trough to frontal processes at $18.5 \mathrm{Ma}$ instead. Throughout this period, eastward flow out of the Scotia Sea would still have been constrained to pass through gaps in the ancestors of the South Sandwich Arc, but at 6 Ma the northern tip of the arc passed east of the southern tip of the South Georgia microcontinent, clearing a new a deep water passageway.

\section{Conclusions}

Synthesis of new and recent plate kinematic studies permits the following summary of the plate tectonic history of the Scotia Sea region. The Scotia Sea grew by plate divergence that was limited by the kinematics of the bounding South American and Antarctic plates, but decoupled from it by the presence of their shared subduction boundary in the northwest Weddell Sea and a long transform fault zone that existed to connect the subduction zone to its counterpart at the Chile Trench. Motion of the trench in the Weddell Sea imparted independent motion to the plates behind it in the Scotia Sea. This was accommodated by a combination of the growth of a succession of small basins and continuing slow motion on the transform fault zone. Early on, the transform fault passed south of Burdwood Bank and the mid-ocean ridges were short and confined to the southern Scotia Sea. With northward propagation of the subduction zone at $30 \mathrm{Ma}$, the transform relocated to the southern edge of the Falkland Plateau and seafloor spreading started on the longer West Scotia Ridge. This continued until $17 \mathrm{Ma}$, when a second mid-ocean ridge initiated in the East Scotia Sea. The two ridges worked simultaneously until the cessation of spreading on the West Scotia Ridge at $\sim 6 \mathrm{Ma}$.

We present these events using nine reconstructions of gridded bathymetric data, and embellish them to form the basis for a set of paleobathymetric sketches. The sketches show a shallow to intermediate-depth gateway opening in the period 50-41 Ma, followed by a deep-water gateway at $30 \mathrm{Ma}$. Based on the sketches, we imagine that oceanographic processes in this early deep gateway would have been strongly affected by the tortuosity of the deep parts of its floor, perhaps leading to a weak and segmented polar front and strong vertical mixing in the embryonic Scotia Sea. Tortuosity would have gradually decreased as more deep ocean floor was accreted to the flanks of the West Scotia Ridge in the period leading up to $20 \mathrm{Ma}$, but eastwards outflow may have continued to be inhibited by an ancestral South Sandwich Arc and continuous North Scotia Ridge. A frontal system organised more like today's would only have become possible with the opening of deep water gaps on the North Scotia Ridge at 18.5-17 Ma, and at the northern end of the East Scotia Sea at $\sim 10 \mathrm{Ma}$.

\section{Acknowledgements}

GE acknowledges the support of Ken McClay and FDRG at RHUL in the presentation of this work at the 2012 IGC in Brisbane. We thank Matthias König for acquiring and processing the central Scotia Sea magnetic anomaly data.

\section{References}

Alabaster, T., Storey, B.C., 1990. Modified Gulf of California model for South Georgia, north Scotia Ridge, and implications for the Rocas Verdes back-arc basin, southern Andes. Geology 18, 497-500.

Alvarez, W., 1982. Geological evidence for the geographical pattern of mantle return flow and the driving mechanism of plate tectonics. J. Geophys. Res. 87, 6697-6710.

Amante, C., Eakins, B.W., 2009. ETOPO1 1 arc-minute global relief model: procedures, data sources and analysis. NOAA Technical Memorandum NESDIS NGDC-24. (19 pp.).

Arctowski, H., 1895. Observations sur l'interet qui presente l'exploration des Terres Australes. Bull. Soc. Geol. Fr. 23, 589-591 (ser. 3).

Arndt, J.E., et al., 2013. The International Bathymetric Chart of the Southern Ocean (IBCSO) version 1.0-a new bathymetric compilation covering circum-Antarctic waters. Geophys. Res. Lett. 40. http://dx.doi.org/10.1002/grl.50413.

Baker, P.E., 1990. The South Sandwich Islands. In: LeMasurier, W.E., Thomson, J.W., LeMasurier, W.E., Thomson, J.W. (Eds.), Volcanoes of the Antarctica Plate and Southern Oceans. American Geophysical Union, Washington, DC, pp. 361-395.

Baker, A.J., Pereira, S.L., Haddrath, O.P., Edge, K.-A., 2006. Multiple gene evidence for expansion of extant penguins out of Antarctica due to global cooling. Proc. R. Soc. Lond. B 217, 11-17.

Barbeau, D.L., 2011. Exhumational history of the margins of Drake Passage from thermochronology and sediment provenance. In: Anderson, J.B., Wellner, J.S. (Eds.), Tectonic, Climatic, and Cryospheric Evolution of the Antarctic Peninsula. American Geophysical Union, Washington, D.C. http://dx.doi.org/10.1029/2010SP000992.

Barbeau, D.L., Olivero, E.B., Swanson-Hysell, N.L., Zahid, K.M., Murray, K.E., Gehrels, G.E., 2009. Detrital zircon geochronology of the eastern Magallanes foreland basin: implications for Eocene kinematics of the northern Scotia Arc and Drake Passage. Earth Planet. Sci. Lett. 284, 489-503. http://dx.doi.org/10.1016/j.epsl.2009.05.014.

Barber, P.L., Barker, P.F., Pankhurst, R.J., 1991. Dredged rocks from Powell Basin and the South Orkney Microcontinent. In: Thomson, M.R.A., Crame, J.A., Thomson, J.W. (Eds.), Geological Evolution of Antarctica. Cambridge University Press, Cambridge, pp. 361-367.

Barker, P.F., 1970. Plate tectonics of the Scotia Sea region. Nature 228, 1293-1296.

Barker, P.F., 1972. Magnetic lineations in the Scotia Sea. In: Adie, R.J. (Ed.), Antarctic Geology and Geophysics. Universitetsforlaget, Oslo, pp. 3-11.

Barker, P.F., 1995. Tectonic framework of the east Scotia Sea. In: Taylor, B. (Ed.), Backarc Basins: Tectonics and Magmatism. Plenum, New York, pp. 281-314.

Barker, P.F., 2001. Scotia Sea regional tectonic evolution: implications for mantle flow and palaeocirculation. Earth Sci. Rev. 55, 1-39.

Barker, D.H.N., Austin Jr., J.A., 1998. Rift propagation, detachment faulting, and associated magmatism in Bransfield Strait, Antarctic Peninsula. J. Geophys. Res. 103, 24017-24043. http://dx.doi.org/10.1029/98JB01117.

Barker, P.F., Burrell, J., 1977. The opening of Drake Passage. Mar. Geol. 25, 15-34.

Barker, P.F., Griffiths, D.H., 1972. The evolution of the Scotia Ridge and Scotia Sea. Philos. Trans. R. Soc. A271, 151-183.

Barker, P.F., Lawver, L.A., 2000. Anomalous temperatures in central Scotia Sea sediments bottom water variation, or pore water circulation in old ocean crust. Geophys. Res. Lett. 27, 13-16.

Barker, P.F., Hill, I.A., Weaver, S.D., Pankhurst, R.J., 1982. The origin of the eastern South Scotia Ridge as an intra-oceanic island arc. In: Craddock, C. (Ed.), Antarctic Geosciences. Univ. Wisc. Press, Madison, pp. 203-211.

Barker, P.F., Barber, P.L., King, E.C., 1984. An early Miocene ridge crest-trench collision on the South Scotia Ridge near 36W. Tectonophysics 102, 315-332.

Barker, P.F., Dalziel, I.W.D., Storey, B.C., 1991. Tectonic evolution of the Scotia Arc region. In: Tingey, R.J. (Ed.), Antarctic Geology. Oxford Univ Press, pp. 215-248.

Barker, P.F., Lawver, L.A., Larter, R.D., 2013. Heat-flow determinations of basement age in small oceanic basins of the southern central Scotia Sea. Geol. Soc. Lond. Spec. Publ. 381. http://dx.doi.org/10.1144/SP381.3.

Barrow, J., 1831. Account of the Island of Deception, one of the New Shetland Isles, introductory note. J. R. Geogr. Soc. Lond. 1, 62.

Bohoyo, F., Galindo Zaldivar, J., Maldonado, A., Schreider, A.A., Surinach, E., 2002. Basin development subsequent to ridge-trench collision; the Jane Basin, Antarctica. Mar. Geophys. Res. 23, 413-421.

Breitsprecher, K., Thorkelsen, D.J., 2009. Neogene kinematic history of Nazca-AntarcticPhoenix slab windows beneath Patagonia and the Antarctic Peninsula. Tectonophysics $464,10-20$.

Brown, B., Gaina, C., Müller, R.D., 2006. Circum-Antarctic palaeobathymetry: illustrated examples from Cenozoic to recent times. Palaeogeogr. Palaeoclimatol. Palaeoecol. 231, 158-168. http://dx.doi.org/10.1016/j.palaeo.2005.07.033.

British Antarctic Survey, 1985, Tectonic map of the Scotia arc 1:3000000 BAS (Misc.) Cambridge, UK. 
Bruguier, N.J., Livermore, R.A., 2001. Enhanced magma supply at the southern East Scotia Ridge: evidence for mantle flow around the subducting slab? Earth Planet. Sci. Lett. 191, 129-144

Bry, M., White, N., Singh, S., England, R., Trowell, C., 2004. Anatomy and formation of oblique continental collision: South Falkland basin. Tectonics 23, TC4011. http://dx.doi.org/10.1029/2002TC001482.

Burrell, J., 1983. The Evolution of Drake Passage. Ph.D. thesis Univ. of Birmingham, Birmingham, UK

Cande, S.C., Stock, J.M., 2004. Cenozoic reconstructions of the Australia-New ZealandSouth Pacific sector of Antarctica. In: Exon, N.F., Kennett, J.P., Malone, M.J. (Eds.), The Cenozoic Southern Ocean: Tectonics, Sedimentation, and Climate Change Between Australia and Antarctica. American Geophysical Union, Washington, DC, pp. 5-18.

Cande, S.C., Stock, J.M., Muller, R.D., Ishihara, T., 2000. Cenozoic motion between East an West Antarctica. Nature 404, 145-150.

Convey, P., Stevens, M.I., Hodgson, D.A., Smellie, J.L., Hillenbrand, C.-D., Barnes, D.K.A. Clarke, A., Pugh, P.J.A., Linse, K., Cary, S.C., 2009. Exploring biological constraints on the glacial history of Antarctica. Quat. Sci. Rev. 28, 3035-3048. http://dx.doi.org/ 10.1016/j.quascirev.2009.08.015.

Coren, F., Ceccone, G., Lodolo, E., Zanolla, C., Zitellini, N., Bonazzi, C., Centonze, J., 1997. Morphology, seismic structure and tectonic development of the Powell Basin, Antarctica. J. Geol. Soc. (London, U.K.) 154, 849-862.

Crough, S.T., 1983. The correction for sediment loading on the seafloor. J. Geophys. Res. 88, 6449-6454.

Cunningham, W.D., Dalziel, I.W.D., Lee, T.-Y., Lawver, L.A., 1995. Southernmost South America-Antarctic Peninsula relative plate motions since $84 \mathrm{Ma}$ : implications for the tectonic evolution of the Scotia Arc region. J. Geophys. Res. 100, 8257-8266.

Cunningham, A.P., Barker, P.F., Tomlinson, J.S., 1998. Tectonics and sedimentary environment of the North Scotia Ridge region revealed by side-scan sonar. J. Geol. Soc (London, U.K.) 155, 941-956.

Dalziel, I.W.D., 1972. K-Ar dating of rocks from Elephant Island, South Scotia Ridge. Geol. Soc. Am. Bull. 83, 1887

Dalziel, I.W.D., 1983. The evolution of the Scotia Arc: a review. In: Oliver, R.L., James, P.R. Jago, J.B. (Eds.), Antarctic Earth Science. Cambridge University Press, Cambridge, pp. 283-288.

Dalziel, I.W.D., Elliot, D.H., 1971. Evolution of the Scotia Arc. Nature 233, 246-251.

Dalziel, I.W.D., Dott Jr., R.H., Winn Jr., R.D., Bruhn, R.L., 1975. Tectonic relations of South Georgia Island to the southernmost Andes. Geol. Soc. Am. Bull. 86, 1034-1040.

Dalziel, I.W.D., Elliot, D.H., Jones, D.L., Thomson, J.W., Thomson, M.R.A., Wells, N.A Zinsmeister, W.J., 1981. The geological significance of some Triassic microfossils from the South Orkney Islands, Scotia Ridge. Geol. Mag. 118, 15-25.

Dalziel, I.W.D., Lawver, L.A., Norton, I.O., Gahagan, L.M., 2013a. The Scotia Arc: genesis, evolution, global significance. Annu. Rev. Earth Planet. Sci. 41, 767-793. http://dx.doi.org/ 10.1146/annurev-earth-050212-124155.

Dalziel, I.W.D., Lawver, L.A., Pearce, J.A., Barker, P.F., Hastie, A.R., Barfod, D.N., Schenke, H.-W., Davis, M.B., 2013b. A potential barrier to deep Antarctic circumpolar flow until the late Miocene? Geology 41, 947-950. http://dx.doi.org/10.1130/G34352.1.

De Conto, R.M., Pollard, D., 2003. Rapid Cenozoic glaciations of Antarctica induced by declining atmospheric $\mathrm{CO}_{2}$. Nature 421, 245-249.

DeWit, M.J., 1977. The evolution of the Scotia Arc as a key to the reconstruction of southwest Gondwanaland. Tectonophysics 37, 53-81.

Dziewonski, A.M., Chou, T.-A., Woodhouse, J.H., 1981. Determination of earthquake source parameters from waveform data for studies of global and regional seismicity. J. Geophys. Res. 86, 2825-2852. http://dx.doi.org/10.1029/JB086iB04p02825.

Eagles, G., 2004. Tectonic evolution of the Antarctic-Phoenix plate system since $15 \mathrm{Ma}$ Earth Planet. Sci. Lett. 217, 97-109. http://dx.doi.org/10.1016/S0012-821X(03) 00584-3.

Eagles, G., 2010a. South Georgia and Gondwana's Pacific margin: lost in translation? J. S Am. Earth Sci. 30, 65-70.

Eagles, G., 2010b. Age and origin of the central Scotia Sea. Geophys. J. Int. 183, 587-600. http://dx.doi.org/10.1111/j.1365-246X.2010.04781.x.

Eagles, G., Livermore, R.A., 2002. Opening history of Powell Basin, Antarctic Peninsula. Mar. Geol. 185, 195-205.

Eagles, G., Scott, B.C.G., 2013. Plate convergence west of Patagonia and the Antarctic Peninsula since 61 Ma. Global Planet. Change (in review)

Eagles, G., Vaughan, A.P.M., 2009. Gondwana breakup and plate kinematics: business as usual. Geophys. Res. Lett. 36, L10302. http://dx.doi.org/10.1029/2009GL037552.

Eagles, G., Gohl, K., Larter, R.D., 2004a. Life of the Bellingshausen plate. Geophys. Res. Lett. 31, L07603. http://dx.doi.org/10.1029/2003GL019127.

Eagles, G., Gohl, K., Larter, R.D., 2004b. High-resolution animated tectonic reconstruction of the South Pacific and West Antarctic Margin. Geochem. Geophys. Geosyst. 5 , Q07002. http://dx.doi.org/10.1029/2003GC000657.

Eagles, G., Livermore, R.A., Fairhead, J.D., Morris, P., 2005. Tectonic evolution of the west Scotia Sea. J. Geophys. Res. 110, B02401.

Eagles, G., Livermore, R.A., Morris, P., 2006. Small basins in the Scotia Sea: the Eocene Drake Passage gateway. Earth Planet. Sci. Lett. 242, 343-353.

Eagles, G., Gohl, K., Larter, R.D., 2009a. Animated tectonic reconstruction of the Southern Pacific and alkaline volcanism at its convergent margins since Eocene times. Tectonophysics 464, 21-29. http://dx.doi.org/10.1016/j.tecto.2007.10.005.

Eagles, G., Larter, R.D., Gohl, K., Vaughan, A.P.M., 2009b. West Antarctic Rift System in the Antarctic Peninsula. Geophys. Res. Lett. 36, L21305. http://dx.doi.org/10.1029/ 2009 GL040721.

Eagles, G., Vaughan, A.P.M., Upchurch, P., 2013. The Weddell Sea, Rocas Verdes basin, and Gondwana Biogeography (in preparation).

Ferraccioli, F., Jones, P.C., Vaughan, A.P.M., Leat, P.T., 2006. New aerogeophysical view of the Antarctic Peninsula: more pieces, less puzzle. Geophys. Res. Lett. 33, L05310. http://dx.doi.org/10.1029/2005GL024636.
Fordyce, R.E., 2003. Cetacea evolution and Eocene-Oligocene oceans revisited. In: Prothero, D.R., Ivany, L.C., Nesbitt, E. (Eds.), From Greenhouse to Icehouse. The Marine Eocene-Oligocene Transition. Columbia University Press, New York, pp. $154-170$.

Forsyth, D.W., 1975. Fault plane solutions and tectonics of the South Atlantic and Scotia Sea. J. Geophys. Res. 80, 1429-1443. http://dx.doi.org/10.1029/JB080i011p01429.

Fretwell, P., et al., 2013. Bedmap2: improved ice bed, surface and thickness datasets for Antarctica. Cryosphere 7, 375-393.

Fretzdorff, S., Livermore, R.A., Devey, C.W., Leat, P.T., Stoffers, P., 2002. Petrogenesis of the Back-arc East Scotia Ridge, South Atlantic Ocean. J. Petrol. 43, 1435-1467. http://dx.doi.org/10.1093/petrology/43.8.1435.

Galindo-Zaldívar, J., Jabaloy, A., Maldonado, A., Sanz de Galdeano, C., 1996. Continental fragmentation along the South Scotia Ridge transcurrent plate boundary (NE Antarctic Peninsula). Tectonophysics 258, 275-301.

Galindo-Zaldívar, J., Bohoyo, F., Maldonado, A., Schreider, A., Suriñach, E., Vázquez, J.T., 2006 Propagating rift during the opening of a small oceanic basin: the Protector Basin (Scotia Arc, Antarctica). Earth Planet. Sci. Lett. 241, 398-412. http://dx.doi.org/10.1016/ j.epsl.2005.11.056.

Garrett, S.W., 1990. Interpretation of reconnaissance gravity and aeromagnetic studies of the Antarctic Peninsula. J. Geophys. Res. 95, 6759-6777.

Garrett, S.W., Renner, R.G.B., Jones, J.A., McGibbon, K.J., 1986. Continental magnetic anomalies and the evolution of the Scotia Arc. Earth Planet. Sci. Lett. 81, 273-281.

Ghidella, M.E., Yáñez, G., LaBrecque, J.L., 2002. Revised tectonic implications for the magnetic anomalies of the western Weddell Sea. Tectonophysics 347, 65-86.

Ghiglione, M.C., Yagupsky, D., Ghidella, M., Ramos, V.A., 2008. Continental stretching preceding the opening of the Drake Passage: evidence from Tierra del Fuego. Geology 36, 643-646.

Goin, FJ., Pascual, R., Tejedor, M. Gelfo, J.N. Woodburne, M. Case, J. Reguero, M., Bond, M., Cione, A., Udrizar Sauthier, D., Balarino, L., Scasso, R., Medina, F.A., Ubaldón, M.C., 2006. The earliest Tertiary therian mammal from South America. J. Vertebr. Paleontol. 26, 505-510.

Gombosi, D.J., Barbeau, D.L., Garver, J., 2009. New thermochronometric constraints on the rapid Paleogene uplift of the Cordillera Darwin complex and related thrust sheets in the Fuegian Andes. Terra Nova 21, 507-515. http://dx.doi.org/10.1111/j.13653121.2009.00908.x.

González-Wevar, C.A., Díaz, A., Gerard, K., Cañete, J.I., Poulin, E., 2012. Divergence time estimations and contrasting patterns of genetic diversity between Antarctic and southern South America benthic invertebrates. Rev. Chil. Hist. Nat. 85, 445-456.

Gradstein, F.M., et al., 2004. A Geologic Time Scale 2004. Cambridge University Press, Cambridge (589 pp.)

Haase, K.M., Beier, C., Fretzdorff, S., Leat, P.T., Livermore, R.A., Barry, T.L., Pearce, J.A., Hauff, F., 2011. Magmatic evolution of a dying spreading axis: evidence for the interaction of tectonics and mantle heterogeneity from the fossil Phoenix Ridge, Drake Passage. Chem. Geol. 280, 115-125. http://dx.doi.org/10.1016/j.chemgeo.2010.11.002.

Hamilton, I.W., 1989. Geophysical Investigations of Subduction Related Processes in the Scotia Sea. PhD thesis University of Birmingham, Birmingham, UK.

Hawkes, D.D., 1962. The structure of the Scotia Arc. Geol. Mag. 99, 85-91.

Hay, W.W., DeConto, R., Wold, C.N., Wilson, J.M., Voigt, S., Schulz, M., Wold-Rossby, A., et al., 1999. Alternative global Cretaceous paleogeography. Geol. Soc. Am. Spec. Pap. 332 $1-47$.

Hernández-Molina, F.J., Bohoyo, F., Naveira Garabato, A., Galindo-Zaldívar, J., Lobo, F.J. Maldonado, A. Rodríguez-Fernández, J., Somoza, L, Stow, D.A.W. Vázquez, J.T. 2007. The Scan Basin evolution: oceanographic consequences of the deep connection between the Weddell and Scotia Seas (Antarctica). International Symposium on Antarctic Earth Science (ISAES) University of California, Santa Barbara (UCSB) August 26-31. USGS OFR-2007. U.S.Geological Survey and The National Academies, pp. 1-4 (Extended Abstract).

Hill, I.A., Barker, P.F., 1980. Evidence for Miocene back-arc spreading in the central Scotia Sea. Geophys. J. R. Astron. Soc. 63, 427-440.

Hospitaleche, C.A., Reguero, M., Scarano, A., 2013. Main pathways in the evolution of the Paleogene Antarctic Sphenisciformes. J. S. Am. Earth Sci. 43, 101-111. http://dx.doi.org/ 10.1016/j.jsames.2013.01.006.

Jokat, W., Boebel, T., König, M., Meyer, U., 2003. Timing and geometry of early Gondwana breakup. J. Geophys. Res. 108, 2428. http://dx.doi.org/10.1029/2002JB001802.

Kavoun, M., Vinnikovskaya, O., 1994. Seismic stratigraphy and tectonics of the northwestern Weddell Sea (Antarctica) inferred from marine geophysical surveys. Tectonophysics 240, 299-323. http://dx.doi.org/10.1016/0040-1951(94)90277-1 (335-341).

Kennett, J.P., 1977. Cenozoic evolution of Antarctic glaciation, the circum-Antarctic Ocean, and their impact on global paleoceanography. J. Geophys. Res. 82, 3843-3860.

King, E.C., Barker, P.F., 1988. The margins of the South Orkney microcontinent. J. Geol. Soc. (London, U.K.) 145, 317-331

King, E.C., Leitchenkov, G., Galindo-Zaldívar, J., Maldonado, A., Lodolo, E., 1997. Crustal structure and sedimentation in Powell Basin. In: Barker, P.F., Cooper, A.K. (Eds.), Geology and Seismic Stratigraphy of the Antarctic margin. Antarct. Res. Ser., 71. AGU, Washington, DC, pp. 75-93.

Klepeis, K.A., Austin Jr., J.A., 1997. Contrasting styles of superposed deformation in the southernmost Andes. Tectonics 16, 755-776.

Klepeis, K., Betka, P., Clarke, G., Fanning, M., Hervé, F., Rojas, L., Mpodozis, C., Thomson, S. 2010. Continental underthrusting and obduction during the Cretaceous closure of the Rocas Verdes rift basin, Cordillera Darwin, Patagonian Andes. Tectonics 29, TC3014. http://dx.doi.org/10.1029/2009TC002610.

Koenitz, D., White, N., McCave, I.N., Hobbs, R., 2008. Internal structure of a contourite drift generated by the Antarctic Circumpolar Current. Geochem. Geophys. Geosyst. 9, Q06012. http://dx.doi.org/10.1029/2007GC001799. 
König, M., Jokat, W., 2006. The Mesozoic breakup of the Weddell Sea. J. Geophys. Res. 111, B12102. http://dx.doi.org/10.1029/2005JB004035.

Kraemer, P.E., 2003. Orogenic shortening and the origin of the Patagonian orocline ( $56^{\circ} \mathrm{S}$ lat.). J. S. Am. Earth Sci. 15, 731-748.

LaBrecque, J.L., Rabinowitz, P.D., 1977. Magnetic Anomalies Bordering the Continental Margin of Argentina. AAPG Map 826.

Lagabrielle, Y., Goddéris, Y., Donnadieu, Y., Malavieille, J., Suarez, M., 2009. The tectonic history of Drake Passage and its possible impacts on global climate. Earth Planet. Sci. Lett. 279, 197-211. http://dx.doi.org/10.1016/j.epsl.2008.12.037.

Larter, R.D., Barker, P.F., 1991. Effects of ridge crest-trench interaction on Antarctic-Phoenix spreading: forces on a young subducting plate. J. Geophys. Res. 96, 19583-19607.

Lawver, L.A., Della Vedova, B., Von Herzen, R.P., 1991. Heat flow in Jane Basin, northwest Weddell Sea. J. Geophys. Res. 96, 2019-2038.

Lawver, L.A., Gahagan, L.M., Coffin, M.F., 1992. The development of paleoseaways around Antarctica. In: Kennett, J.P., Warkne, D.A. (Eds.), The Antarctic Paleoenvironment: A Perspective on Global Change: Part One. Antarct. Res. Ser., vol. 56. AGU, Washington, D.C., pp. 7-30. http://dx.doi.org/10.1029/AR056p0007.

Lawver, L.A., Gahagan, L.M., Dalziel, I.W.D., 2011. A different look at gateways: Drake Passage and Australia/Antarctica. In: Anderson, J.B., Wellner, J.S. (Eds.), Tectonic, Climatic, and Cryospheric Evolution of the Antarctic Peninsula. American Geophysical Union, Washington, D.C. http://dx.doi.org/10.1029/2010SP001017.

Leng, W., Gurnis, M., 2011. Dynamics of subduction initiation with different evolutionary pathways. Geochem. Geophys. Geosyst. 12, Q12018. http://dx.doi.org/10.1029/ 2011GC003877.

Livermore, R.A., Hunter, R., 1996. Mesozoic seafloor spreading in the southern Weddell Sea. In: Storey, B., King, E., Livermore, R. (Eds.), Weddell Sea Tectonics and Gondwana Breakup. Geol. Soc. Spec. Publ., 108, pp. 227-241.

Livermore, R.A., Woollett, R.W., 1993. Seafloor spreading in the Weddell Sea and southwest Atlantic since the Late Cretaceous. Earth Planet. Sci. Lett. 117, 475-495. http://dx.doi.org/10.1016/0012-821X(93)90098-T.

Livermore, R.A., McAdoo, D., Marks, K., 1994. Scotia Sea tectonics from high-resolution satellite gravity. Earth Planet. Sci. Lett. 123, 255-268.

Livermore, R., Cunningham, A., Vanneste, L., Larter, R., 1997. Subduction influence on magma supply at the East Scotia Ridge. Earth Planet. Sci. Lett. 150, 261-275.

Livermore, R.A., Eagles, G., Morris, P., Maldonado, A., 2004. Shackleton Fracture Zone: no barrier to early circumpolar ocean circulation. Geology 32, 797-800.

Livermore, R.A., Nankivell, A.P., Eagles, G., Morris, P., 2005. Paleogene opening of Drake Passage. Earth Planet. Sci. Lett. 236, 459-470.

Lodolo, E., Donda, F., Tassone, A., 2006. Western Scotia Sea margins: improved constraints on the opening of the Drake Passage. J. Geophys. Res. 111, B06101. http://dx.doi.org/ 10.1029/2006JB004361.

Lodolo, E., Civile, D., Vuan, A., Tassone, A., Geletti, R., 2010. The Scotia-Antarctica plate boundary from $35^{\circ} \mathrm{W}$ to $45^{\circ} \mathrm{W}$. Earth Planet. Sci. Lett. 293, 200-215. http://dx.doi.org/ 10.1016/j.epsl.2009.12.045.

Macfadyen, W.A., 1933. Fossil foraminifera from the Burdwood Bank and their geological significance. Discov. Rep. 7, 1-16.

Maldonado, A., Zitellini, N., Leitchenkov, G., Balanyá, J.C., Coren, F., Galindo-Zaldívar, J., Lodolo, E., Jabaloy, A., Zanolla, C., Rodríguez-Fernández, J., Vinnikovskaya, O., 1998. Small ocean basin development along the Scotia-Antarctica plate boundary and in the northern Weddell Sea. Tectonophysics 296, 371-402.

Maldonado, A., et al., 2003. Contourite deposits in the central Scotia Sea: the importance of the Antarctic Circumpolar Current and the Weddell Gyre flows. Palaeogeogr. Palaeoclimatol. Palaeoecol. 198, 187-221.

Mao, S., Mohr, B.A.R., 1995. Middle Eocene dinocysts from Bruce Bank (Scotia Sea, Antarctica) and their paleoenvironmental and paleogeographic implications. Rev. Palaeobot. Palynol. 86, 235-263.

Matthews, D.H., 1959. Aspects of the geology of the Scotia arc. Geol. Mag. 96, 425-441.

Müller, R.D., Sdrolias, M., Gaina, C., Roest, W.R., 2008. Age spreading rates and spreading asymmetry of the world's ocean crust. Geochem. Geophys. Geosyst. 9, Q04006. http://dx.doi.org/10.1029/2007GC001743.

Nankivell, A.P., 1997. Tectonic Evolution of the Southern Ocean Between Antarctica, South America and Africa Over the Last 84 Ma. Ph.D. thesis Univ. of Oxford, Oxford, UK.

Nerlich, R., Clark, S.R., Bunge, H.-P., 2013. The Scotia Sea gateway: No outlet for Pacific mantle. Tectonophysics 604, 41-50. http://dx.doi.org/10.1016/j.tecto.2012. 08.023.

Nicholson, B., Georgen, J., 2013. Controls on crustal accretion along the back-arc East Scotia Ridge: constraints from bathymetry and gravity data. Mar. Geophys. Res. 34, 45-58.

ODSN Plate Reconstruction Service, a. www.odsn.de/odsn/services/paleomap/paleomap. html.

Pandey, A., Parson, L., Milton, A., 2010. Geochemistry of the Davis and Aurora Banks: possible implications on evolution of the North Scotia Ridge. Mar. Geol. 268, 106-114.

Pankhurst, R.J., Rapela, C.W., 1995. Production of Jurassic rhyolite by anatexis of the lower crust of Patagonia. Earth Planet. Sci. Lett. 134, 23-36.

Parsons, B., Sclater, J.G., 1977. An analysis of the variation of ocean floor bathymetry and heat flow with age. J. Geophys. Res. 82, 803-827. http://dx.doi.org/10.1029/ JB082i005p00803.

Pearce, J.A., Leat, P.T., Barker, P.F., Millar, I.L., 2001. Geochemical tracing of Pacific-toAtlantic upper-mantle flow through the Drake Passage. Nature 410, 457-461.

Pearce, J.A., Hastie, A.R., Leat, P.T., Dalziel, I.W., Lawver, L.A., Barker, P.F., Millar, I.L., Barry, T.L., Bevins, R.E., 2013. The initiation and evolution of the early South Sandwich island arc system, South Atlantic. Glob. Planet. Chang. (submitted for publication).

Pelayo, A.M., Wiens, D.A., 1989. Seismotectonics and relative plate motions in the Scotia Sea region. J. Geophys. Res. 94, 7293-7320. http://dx.doi.org/10.1029/JB094iB06p07293.
Pérez-Díaz, L., Eagles, G., 2013. Growth of the South Atlantic Ocean by Seafloor Spreading (submitted for publication)

Pfuhl, H.A., McCave, I.N., 2005. Evidence for late Oligocene establishment of the Antarctic Circumpolar Current. Earth Planet. Sci. Lett. 235, 715-728.

Pirie, J.H.H., 1905. On the graptolite-bearing rocks of the South Orkneys. Proc. R. Soc. Edinb. 25, 463-470.

Polonia, A., Brancolini, G., Torelli, L., Vera, E., 1999. Structural variability at the active continental margin off Southernmost Chile. J. Geodyn. 27, 289-307.

Puig, A., Herve, M., Suarez, M., Saunders, A.D., 1984. Calc-alkaline and alkaline Miocene and calc-alkaline recent volcanism in the southernmost Patagonian cordillera, Chile. J. Volcanol. Geotherm. Res. 21, 149-163.

Reguero, M.A., Marenssi, S.A., 2010. Paleogene climatic and biotic events in the terrestrial record of the Antarctic Peninsula: an overview. In: Madden, R.H., Carlini, A.A., Vucetich, M.G., Kay, R.F. (Eds.), The Paleontology of Gran Barranca - Evolution and Environmental Change Through the Middle Cenozoic of Patagonia. Cambridge University Press, Cambridge, U.K., pp. 383-397.

Roterman, C.N., Copley, J.T., Linse, K.T., Tyler, P.A., Rogers, A.D., 2013. The biogeography of the yeti crabs (Kiwaidae) with notes on the phylogeny of the Chirostyloidea (Decapoda: Anomura). Proc. R. Soc. B 280. http://dx.doi.org/10.1098/rspb.2013.0718 (20130718).

Sandwell, D.T., Smith, W.H.F. 2009. Global marine gravity from retracked Geosat and ERS-1 altimetry: ridge segmentation versus spreading rate. J. Geophys. Res. 114, B01411.

Schenke, H.-W., Udintsev, G.B., 2009. The Central Scotia Sea floor-is it an paleo-oceanic plate, an young rifted plate or an paleo-Land Scotia? Ukr. Antarct. J. 8, 36-45.

Scher, H.D., Martin, E.E., 2006. Timing and climatic consequences of the opening of Drake Passage. Science 312, 428-430.

Schreider, A.A., Schreider, Al.A., Kashintsev, G.L., Galinado-Zaldivar, J., Maldonado, A., Boiko, A.N., Evsenko, E.I., 2011. Peculiarities of the East Scotia ridge's geochronology. Oceanology 51, 1047-1060.

Schreider, Al.A., Schreider, A.A., Galindo-Zaldívar, J., Maldonado, A., Martos-Martin, Y., 2012. Initial phase of the West Scotia mid-oceanic spreading. Oceanology 52, 540-544.

Sijp, W.P., England, M.H., 2005. Role of the Drake Passage in controlling the stability of the ocean's thermohaline circulation. J. Clim. 18, 1957-1966. http://dx.doi.org/10.1175/ JCLI3376.1.

Small, C., 1998. Global systematics of mid-ocean ridge morphology. In: Buck, W.R., Delaney, P.T., Karson, J.A., Lababrielle, Y. (Eds.), Faulting and Magmatism at Midocean Ridges. American Geophysical Union Monograph, 106. AGU, Washington, D.C., pp. $1-25$

Smalley Jr., R., Kendrick, E., Bevis, M.G., Dalziel, I.W.D., Taylor, F., Lauría, E., Barriga, R. Casassa, G., Olivero, E., Piana, E., 2003. Geodetic determination of relative plate motion and crustal deformation across the Scotia-South America plate boundary in eastern Tierra del Fuego. Geochem. Geophys. Geosyst. 4, 1070. http://dx.doi.org/10.1029/ 2002 GC000446.

Smalley, R., Dalziel, I.W.D., Bevis, M.G., Kendrick, E., Stamps, D.S., et al., 2007. Scotia arc kinematics from GPS geodesy. Geophys. Res. Lett. 34, L21308.

Steeman, M.E., Hebsgaard, M.B., Fordyce, R.E., Ho, S.Y.W., Rabosky, D.L., Nielsen, R. Rahbek, C., Glenner, H., Sørensen, M.V., Willersley, E., 2009. Radiation of extant cetaceans driven by restructuring of the oceans. Syst. Biol. 58, 573-585.

Stein, C., Stein, S., 1992. A model for the global variation in oceanic depth and heat flow with lithospheric age. Nature 359, 123-128.

Stock, J.M., Molnar, P., 1987. Revised early Tertiary history of plate motions in the Southwest Pacific. Nature 325, 495-499.

Stone, P., Kimbell, G.S., Richards, P.C., 2009. Rotation of the Falklands microplate reassessed after recognition of discrete Jurassic and Cretaceous dyke swarms. Pet. Geosci. 15, 279-287.

Storey, B.C., Mair, B.F., Bell, C.M., 1977. The occurrence of Mesozoic oceanic floor and ancient continental crust on South Georgia. Geol. Mag. 114, 203-208.

Suess, E., 1909. Das Antlitz der Erde. Freytag, Leipzig. 3 volumes.

Taylor, G.K., Shaw, J., 1989. The Falkland Islands: new paleomagnetic data and their origin as a displaced terrane from Southern Africa. In: Hillhouse, J.W. (Ed.), Deep structure and past kinematics of accreted terranes, pp. 59-72 (AGU Monograph 50).

Tebbens, S.F., Cande, S.C., 1997. Southeast Pacific tectonic evolution from early Oligocene to present. J. Geophys. Res. 102, 12061-12084.

Thomas, C., Livermore, R., Pollitz, F., 2003. Motion of the Scotia Sea plates. Geophys. J. Int. $155,789-804$

Tilley, C.E., 1935. Report on rocks from the South Orkney Islands. Discov. Rep. 10, 383-390.

Toggweiler, J.R., Bjornsson, H., 2000. Drake Passage and paleoclimate. J. Quat. Sci. 15, 319-328.

Trendall, A.F., 1953. The geology of South Georgia: I. Falkland Islands Dependencies Survey Scientific Reports. 7 (26 pages).

Trendall, A.F., 1959. The geology of South Georgia: II. Falkland Islands Dependencies Survey Scientific Reports. 19 (48 pages).

Tyrrell, G.W., 1945. Report on rocks from West Antarctica and the Scotia Arc. Discov. Rep. $23,37-102$.

Udintsev, G.B., Kurentsova, N.A., Beresnev, A.F., Kol'tsova, A.V., Domoratskaya, L.G., Schenke, G.V., Bakhmutov, V.G., Solov'ev, V.D., 2012. Tectonics of the drake Passage-Scotia sea zone in the southern ocean. Dokl. Earth Sci. 445, 1029-1035.

Vanneste, L.E., Larter, R.D., 2002. Sediment subduction, subduction erosion and strain regime in the northern South Sandwich forearc. J. Geophys. Res. 107, 2149. http://dx.doi.org/10.1029/2001JB000396.

Vérard, C., Flores, K., Stampfli, G., 2012. Geodynamic reconstructions of the South America-Antarctica plate system. J. Geodyn. 53, 43-60. http://dx.doi.org/10.1016/j. jog.2011.07.007. 
Wilson, J.T. 1966. Are the structures of the Caribbean and Scotia Arc regions analogous to ice rafting? Earth Planet. Sci. Lett. 1, 335-338.

Wilson, D.S., Jamieson, S.S.R., Barrett, P.J., Leitchenkov, G., Gohl, K., Larter, R.D., 2012 Antarctic topography at the Eocene-Oligocene boundary. Palaeogeogr. Palaeoclimatol. Palaeoecol. 335-336, 24-34.

Wobbe, F., Gohl, K., Chambord, A., Sutherland, R., 2012. Structure and breakup history of the rifted margin of West Antarctica in relation to Cretaceous separation from
Zealandia and Bellingshausen plate motion. Geochem. Geophys. Geosyst. 13, Q04W12. http://dx.doi.org/10.1029/2011GC003742.

Woodburne, M.O., Case, J.A., 1996. Dispersal, vicariance, and the Late Cretaceous to early Tertiary land mammal biogeography from South America to Australia. J. Mamm. Evol. $3,121-161$.

Zlotnicki, V., Sclater, J.G., Norton, I.O., Von Herzen, R.P., 1980. Heat-flow through the floor of the Scotia, far South-Atlantic and Weddell Seas. Geophys. Res. Lett. 7, 421-422. 